\title{
SYSTEMATIC REVISION AND EVOLUTIONARY HISTORY OF ACARECHIMYS PATTERSON IN KRAGLIEVICH, 1965 (RODENTIA, CAVIOMORPHA, OCTODONTOIDEA)
}

\author{
MICHELLE ARNAL ${ }^{1,6}$, MARÍA G. VUCETICH2,6, DARIN A. CROFT³, M. SUSANA BARGO1,7, JUAN C. FERNICOLA ${ }^{4,5,6}$, AND SERGIO F. \\ VIZCAINO1,6 \\ 1Unidades de Investigación, Anexo Museo de La Plata, FCNyM-UNLP, Av. 122 y 60, CP 1900, La Plata, Argentina. michoarnal@gmail.com.ar; msbargo@fcnym.unlp.edu.ar; \\ vizcaino@fcnym.unlp.edu.ar \\ 2Museo de La Plata, Museo de La Plata, FCNyM-UNLP, Paseo del Bosque s/n, CP 1900, La Plata, Argentina. vucetich@fcnym.unlp.edu.ar \\ 32Department of Anatomy, Case Western Reserve University School of Medicine, 10900 Euclid Ave., Cleveland, OH 44106-4930, USA. darin.croft@case.edu \\ 4Museo Argentino de Ciencias Naturales 'Bernardino Rivadavia', Av. Ángel Gallardo 470, 1405DJR, Ciudad Autónoma de Buenos Aires, Argentina. jctano@yahoo.com \\ ${ }^{5}$ Departamento de Ciencias Básicas, Universidad Nacional de Luján, Ruta 5 y Avenida Constitución, 6700 Luján, Buenos Aires, Argentina. \\ ${ }^{6}$ CONICET \\ ${ }^{7} \mathrm{CIC}$
}

\begin{abstract}
The octodontoid rodent Acarechimys was abundant during the early Miocene and had the widest temporal and geographic distribution of any extinct caviomorph. Despite this extensive fossil record Acarechimys has not been well characterized. In this work, we systematically revise Acarechimys, describe new early-middle Miocene fossils from Argentina and Bolivia, corroborate its monophyly, and study its evolutionary history. Acarechimys has brachydont molars, retained deciduous premolars, four crests on upper molars, lowers with variably developed mesolophid and metalophulid II, and absence of mental foramen in the mandible. Acarechimys includes: Acarechimys leucotheae (late Oligocene, Chubut, Argentina), A. gracilis and A. constans (early Miocene, Chubut and Santa Cruz, Argentina), and A. minutus and A. minutissimus (earlymiddle Miocene of Patagonia Argentina, Bolivia, and Colombia). The temporal and geographic distributions suggest that Acarechimys could have evolved in Patagonia, by the early late Oligocene. Its acme was during the late early Miocene in Southern Patagonia. By the middle Miocene, Acarechimys decreased in diversity and was last recorded in high latitudes of South America (Patagonia). In lower latitudes, the oldest record is from the late early Miocene of Chucal, northern Chile, and during the late middle Miocene, the genus is recorded in localities of Colombia, Bolivia, and Peru. The available evidence suggests that Acarechimys was probably not present in lower latitudes ( $\mathrm{N}$ of $\sim 30^{\circ} \mathrm{S}$ ) before the early Miocene. The reasons Acarechimys dispersed northward at this time remain to be elucidated, but the timing coincides with a massive disappearance of other octodontoids from Patagonia.
\end{abstract}

Key words. Octodontoid. Oligocene. Miocene. South America. Evolutionary history.

Resumen. REVISIÓN SISTEMÁTICA E HISTORIA EVOLUTIVA DE ACARECHIMYSPATTERSON EN KRAGLIEVICH, 1965 (RODENTIA, CAVIOMORPHA, OCTODONTOIDEA). El roedor octodontoideo Acarechimys fue abundante durante el Mioceno temprano y tuvo la distribución geográfica y temporal más amplia para un caviomorfo viviente. A pesar de su amplio registro fósil Acarechimys nunca fue caracterizado correctamente. En este trabajo, realizamos la revisión sistemática de Acarechimys, describimos nuevos materiales del Mioceno temprano-medio de Argentina y Bolivia, corroboramos su monofilia y estudiamos su historia evolutiva. Acarechimys presenta dientes braquiodontes, retención de premolares deciduos, cuatro crestas en molares superiores, desarrollo variable del mesolófido y el metalofúlido II en molares inferiores y ausencia de foramen mentoniano en la mandíbula. Acarechimys incluye: Acarechimys leucotheae (Oligoceno tardío, Chubut, Argentina), A. gracilis y A. constans (Mioceno temprano, Chubut y Santa Cruz, Argentina), y A. minutus y A. minutissimus (Mioceno temprano-medio de Patagonia Argentina, Bolivia y Colombia). Su distribución temporal y geográfica sugiere que Acarechimys habría evolucionado en Patagonia en el Oligoceno tardío-temprano. Su acmé fue en el Mioceno temprano-tardío en el sur de Patagonia. Para el Mioceno medio Acarechimys disminuyó su diversidad y tiene su último registro en latitudes altas de América del Sur (Patagonia). En latitudes bajas, el registro más antiguo proviene del Mioceno tempranotardío de Chucal, norte de Chile, y durante el Mioceno medio se lo registra en localidades de Colombia, Bolivia y Perú. La evidencia disponible sugiere que Acarechimys probablemente no estuvo presente en bajas latitudes ( $\mathrm{N}$ de $30^{\circ} \mathrm{S}$ ) antes del Mioceno temprano. Las causas de su dispersión hacia el norte deben ser todavía estudiadas, aunque la misma coincide con la desaparición masiva de octodontoideos en Patagonia.

Palabras clave. Octodontoideo. Oligoceno. Mioceno. América del Sur. Historia evolutiva.

ACARECHIMYS is an extinct rodent genus, part of the richest and most diverse clade of caviomorphs: Octodontoidea. It represents a successful evolutionary lineage with unusually wide temporal (late Oligocene-late Miocene) and geo- 
graphic distributions (southern Argentinean Patagonia to Colombia); it was one of the most abundant octodontoids during the Burdigalian (late early Miocene; Santacrucian South American Land Mammal Age, SALMA; Pascual et al., 1965) of Santa Cruz Province, Argentina.

Ameghino (1887), while working at the Museo de La Plata (MLP), erected the genera Acaremys, Stichomys, and Sciamys, and recognized the species: Acaremys minutus, $A$. minutissimus, Sciamys tenuissimus, and Stichomys constans. Subsequently, he named additional species of these genera (Ameghino, 1889, 1891, 1894). Scott (1905) performed an exhaustive revision of the rodents from the Santa Cruz Formation based on fossils collected by the Princeton Expeditions to Patagonia (1896-1899; housed at the Yale Peabody Museum, New Haven, USA) and the collections housed in the museums of Buenos Aires and La Plata that he visited in 1902. As a result, he described additional materials and performed detailed descriptions of Acaremys minutus, A. minutissimus, Sciamys tenuissimus, Stichomys constans, and Stichomys diminutus. Bryan Patterson studied the paleontology collections deposited at the MLP and MACN in the years 1952-1954 (Olson, 1985) and performed an exhaustive investigation of caviomorphs that was never published. Nevertheless, in his unpublished manuscript (UMS, available at the Vertebrate Paleontology Section, MACN), Patterson provided information that was later used by Pascual (1967) and by the authors of this work (see below). The genus Acarechimys was first mentioned by Kraglievich (1965) in a footnote, explaining: 'Ce nom, inédit, a été appliqué par B. Patterson à l'espèce Acaremys minutus Amegh. (Patterson et Kraglievich, ms.). Later, based on Patterson UMS, Pascual (1967) mentioned the genus Acarechimys with the species Acarechimys minutus, Acarechimys minutissimus, and Acarechimys constans, and provided collection numbers of the lectotype of each species. Finally, Patterson (in Patterson and Wood, 1982) characterized the genus Acarechimys for the Santacrucian SALMA of Patagonia, with Acarechimys minutus as the type species (synonym: Stichomys gracilis Ameghino, 1891) and Acarechimys minutissimus as the only other referred species (synonyms: Stichomys diminutus Ameghino, 1891, Sciamys tenuissimus Ameghino, 1894, and provisionally Stichomys constans Ameghino, 1887). Since the 1990s, the genus Acarechimys has been recognized at numerous localities beyond Santa
Cruz Province: Vucetich et al. (1993a) extended its biochron by describing Acarechimys sp. from the Langhian (early middle Miocene, Colloncuran SALMA) of Neuquén Province, Argentinean Patagonia; Walton (1997) identified Acarechimys cf. A. minutissimus from the Serravallian (late middle Miocene, Laventan SALMA) of La Venta, Colombia, and Croft et al. (2011) described new specimens of Acarechimys from the Serravallian (late middle Miocene, Laventan SALMA) of Quebrada Honda, Bolivia. Flynn et al. $(2002,2008)$ and Croft et al. (2007) mentioned Acarechimys for the early to middle Miocene of Chile, Antoine et al. (2016) for the early Miocene of Contamana, Peru, Tejada-Lara et al. (2015) for middle Miocene of the Fitzcarrald Arch in the Peruvian Amazonia, and Esteban et al. (2014) for late Miocene-early Pliocene of the Andalhuala and Chiquimil formations in Catamarca Province, Argentina.

Vucetich et al. (2010) transferred the species Protacaremys pulchellus Ameghino, 1902 to Acarechimys, erecting the

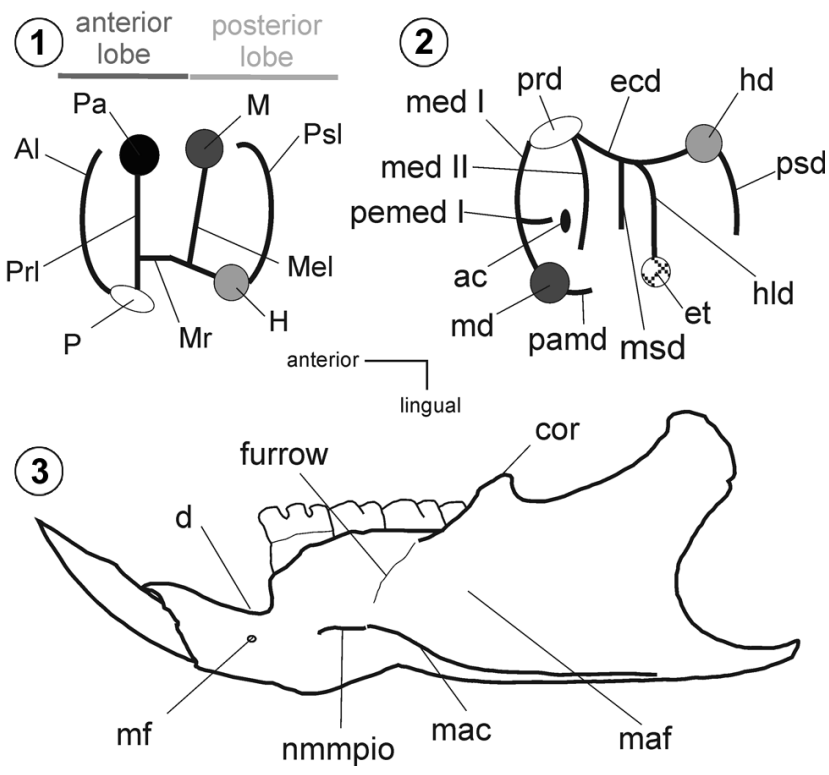

Figure 1. Dental and mandibular nomenclature used in this work. 1, upper cheek teeth: Al, anteroloph; $\mathrm{H}$, hypocone; $\mathrm{M}$, metacone; Mel, metaloph; Mr, mure; P, protocone; Pa, paracone; Prl, protoloph; Psl, posteroloph; 2, lower cheek teeth: ac, accessory cusp; ecd, ectolophid; et, entoconid; hd, hypoconid; hld, hypolophid; md, metaconid; med I, metalophulid I; med II, metalophulid II; msd, mesolophid; pamd, posterior arm of the metaconid; pemed I, posterior extension of the metalophulid I; prd, protoconid; psd, posterolophid; 3, mandible: cor, coronoid process; d, diastema; mac, masseteric crest; maf, masseteric fossa; mf, mental foramen; nmmpio, notch for the insertion of the masseter muscle, pars infraorbitalis. 
new combination Acarechimys pulchellus (Ameghino, 1902) for the Aquitanian-Burdigalian (early Miocene, Colhuehuapian SALMA) of Patagonia. This taxonomic assignation was corroborated later by Arnal (2012) with a cladistic analysis. Vucetich et al. (2015a) described the most ancient species of the genus, Acarechimys leucotheae, from the Chattian (late Oligocene, Deseadan SALMA c.a. 29.4-24.2 $\mathrm{Ma}$ ) of Cabeza Blanca, Chubut Province, Argentina. Recently, Verzi et al. (2016) reviewed and revised specimens included in this genus.

In this contribution, we review nearly all of the material hitherto assigned to Acarechimys, and describe new specimens with precise geographic and stratigraphic provenance from the Santa Cruz Formation (late early Miocene of Santa Cruz Province, Argentina), Collon Curá Formation (early middle Miocene of Neuquén Province, Argentina), and an unnamed formation in southern Bolivia (late middle Miocene of Quebrada Honda).

\section{MATERIALS AND METHODS}

A total of 127 specimens were studied (Supplementary appendix 1). Dental nomenclature follows Marivaux et al. (2002), Candela and Rasia (2012), and Arnal et al. (2014). Mandibular and cranial nomenclature follows Wible et al. (2005) and Woods and Howland (1979) (Fig. 1).

Institutional abbreviations. MACN-A, Museo Argentino de Ciencias Naturales 'Bernardino Rivadavia', Ameghino National Collection, Buenos Aires, Argentina; MACN-PV, Museo Argentino de Ciencias Naturales 'Bernardino Rivadavia', Vertebrate Paleontology Collection, Buenos Aires, Argentina; MLP, Museo de La Plata, La Plata, Argentina; MPM-PV, Museo Regional Provincial 'Padre Manuel Jesús Molina', Vertebrate Paleontology Collection, Santa Cruz, Argentina; UATF-V, Universidad Autónoma Tomás Frías, Vertebrate Paleontology Collection, Potosí, Bolivia; YPM-VPPU, Princeton University Collection of the Yale Peabody Museum, New Haven, USA.

Systematic revision. Recognition of the type series used by Florentino Ameghino $(1887,1889)$ was necessary to identify the specimens recovered by Carlos Ameghino during his fieldtrip of 1887 in the cliffs of the Santa Cruz River, Santa Cruz province, Argentina (Fig. 2). In performing this investigation, we took into account different sources of information: Ameghino's catalog at the MACN, the MLP catalog,
Patterson's UMS, collection labels and file cards, and the account of the history of the conflict between F. Ameghino and Moreno when the Santacrucian species were erected (Fernicola, 2011). Patterson studied the paleontology collections deposited at the MLP and MACN, but identified lectotypes and syntypes of fossils housed at the MLP [information that was published by Pascual (1967)]. Patterson mentioned and studied specimens figured by Ameghino (1889) and deposited at the MACN but dismissed the possibility that they might be holotypes because he believed that the fossils collected by C. Ameghino in 1887 were deposited exclusively at the MLP (UMS, pers. comm.). Fernicola (2011) determined that those fossils figured in the Atlas by Ameghino (1889) and housed in the MACN were collected by his brother Carlos in 1887, and therefore these fossils could be part of the type series of taxa founded in 1887 by F. Ameghino. Additionally, we have inferred that Patterson may have had access to labels with Ameghino's handwriting and other certain provenance information, since his UMS stresses differences among 'labeled materials', 'improperly labeled materials', and 'materials that agree with Ameghino's original descriptions'. Thus, with some exceptions (see below), we accept the information provided by Patterson in his unpublished manuscript and discuss the implications for each particular species.

Statistical analyses. In order to test for size differences among Acarechimys species, we performed statistical analyses using $\mathrm{m} 1$ and $\mathrm{m} 2$ length, as these allowed for the largest sample sizes. Sixty-nine $\mathrm{m} 1$ and $62 \mathrm{~m} 2$ measurements were used in the analyses. Statistical analyses were performed using JMP Pro (SAS Institute, Inc., 2013).

Cladistic analysis. In order to test the monophyly of the genus, we used an expanded and modified version of the data matrix of Arnal and Vucetich (2015) (Supplementary appendices 2 and 3). In total, it consists of 186 morphological characters and 59 taxa. These include 19 morphological characters from Verzi et al. (2016) that were added in order to evaluate comparable data matrices. The living Abrocoma was included in order to test whether some Acarechimys species group within Abrocomidae. The data matrix was analyzed under equally weighted parsimony using TNT 1.5 (Goloboff and Catalano, 2016). A heuristic search of 1,000 replications of Wagner trees (with random addition sequence) followed by Tree Bisection and Recon- 
nection (TBR) branch-swapping algorithm (holding 10 trees per replicate) was conducted. The best trees obtained at the end of the replicates were subjected to a final round of TBR

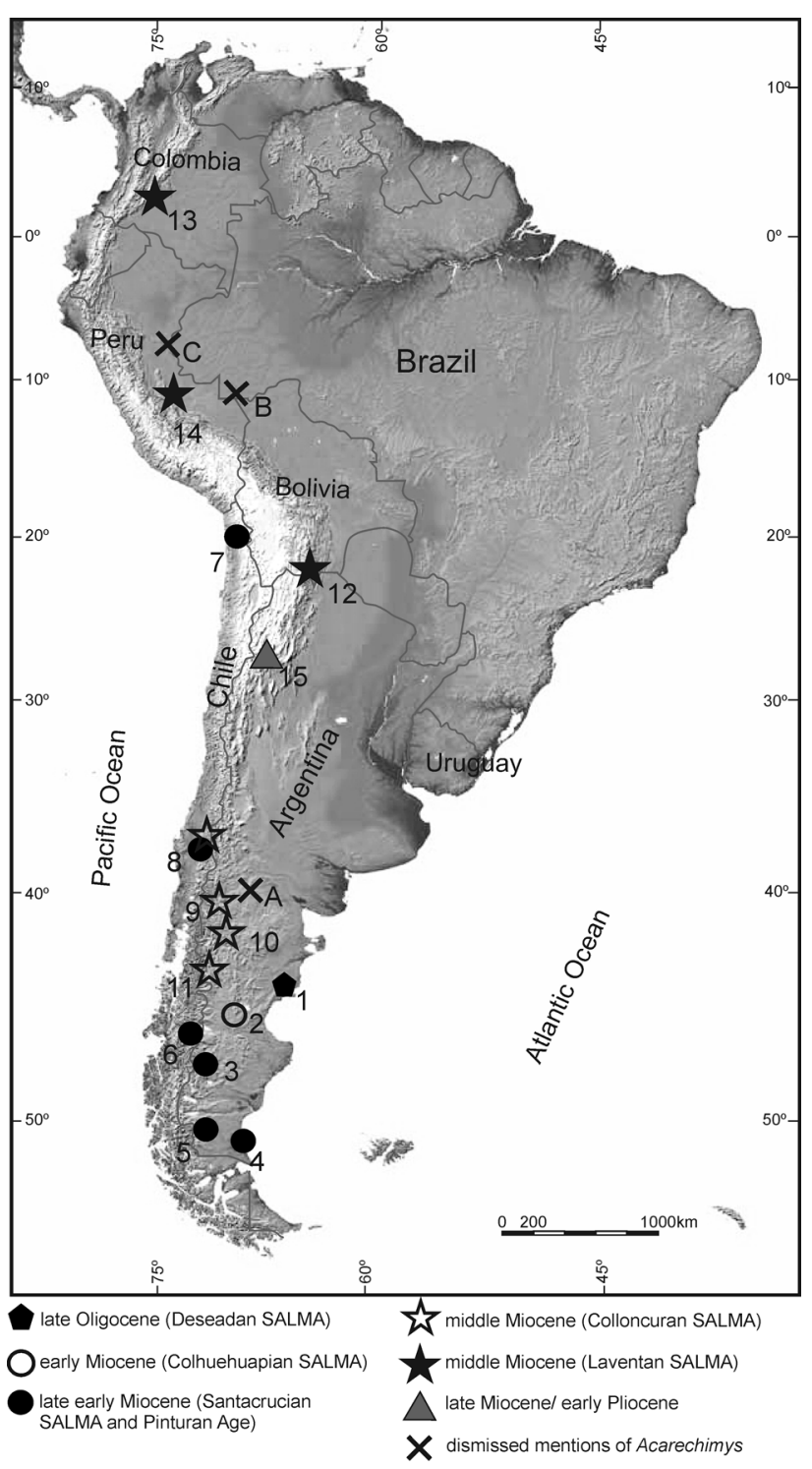

Figure 2. Map showing fossil localities where Acarechimys has been found or mentioned. 1, Cabeza Blanca, Chubut, Argentina; 2, Gran Barranca, Chubut, Argentina; 3, Río Pinturas Valley, Santa Cruz, Argentina; 4, coastal localities of the Santa Cruz Formation, Santa Cruz, Argentina; 5, localities at the cliffts of the Río Santa Cruz, Santa Cruz, Argentina; 6, Pampa Castillo, Región XI, Chile; 7, Chucal Formation, Región XV, Chile; 8, Laguna del Laja (Curá Mallín Formation), Región VIII, Chile; 9, Cañadón del Tordillo, Neuquén, Argentina; 10, El Petiso, Chubut, Argentina; 11, Huemules River (Río Mayo Formation), Chubut, Argentina; 12, Quebrada Honda, Bolivia; 13, La Venta, Colombia; 14, Fitzcarrald Arch, Peru; 15, Puerta de Corral Quemado y Villavil (Andalhuala and Chiquimil formations), Argentina. A, B, and C refer to dismissed mentions of Acarechimys ( $A$, Chichinales Formation, Río Negro, Argentina; B; Madre de Dios Formation, Peru; C; Pebas Formation, Peru). branch swapping. Thirty-one characters were treated as ordered. The robustness of the obtained MPTs was calculated with relative and absolute Bremer supports (Bremer, 1994; Goloboff and Farris, 2001).

\section{SYSTEMATIC PALEONTOLOGY}

\section{Order Rodentia Bowditch, 1821}

Suborder HystRICOgnathI Tullberg, 1899

Parvorder Caviomorpha Wood, 1955

Superfamily OctodontoIdeA Waterhouse, 1839

Genus Acarechimys Patterson in Kraglievich, 1965

Type species. Acaremys minutus Ameghino, 1887.

1887. Stichomys Ameghino, partim. p. 10.

1887. Sciamys Ameghino, partim. p. 312.

2016. Ameghinomys Verzi, Olivares and Morgan, pp. 412-413.

Stratigraphic and geographic occurrences. Upper levels of the Sarmiento Formation at Cabeza Blanca (Chubut, Argentina), late Oligocene, Deseadan SALMA (Vucetich et al., 2015 a); Sarmiento Formation (Chubut, Argentina), early Miocene, Colhuehuapian SALMA (Vucetich et al., 2010); Pinturas Formation (Santa Cruz, Argentina), late early Miocene, 'Pinturan' age (Kramarz and Bellosi, 2005); Santa Cruz Formation, (Santa Cruz, Argentina), late early Miocene, Santacrucian SALMA (Ameghino, 1887, 1889; Scott, 1905; Vizcaíno et al., 2012); Chucal Formation (Región XV, Chile), late early Miocene, Santacrucian SALMA (Croft et al., 2007); unnamed formation (Pampa Castillo, Región XI, Chile), late early Miocene, Santacrucian SALMA (Flynn et al., 2002); Curá Mallín Formation (Región VIII, Laguna del Laja, Chile), early to middle Miocene (Flynn et al., 2008); Collon Curá Formation (Neuquén, Argentina), early middle Miocene, Colloncuran SALMA (Vucetich et al., 1993a); Villavieja Formation (Colombia), late middle Miocene, Laventan SALMA (Walton, 1997); unnamed formation (Quebrada Honda, Bolivia), late middle Miocene, Laventan SALMA (Croft et al., 2011); unspecified formation, Fitzcarrald Arch (Peru), middle Miocene, Laventan SALMA (Negri et al., 2010; Tejada-Lara et al., 2015); Pebas Formation, Contamana (Peru), late? Miocene (Antoine et al., 2016).

Emended diagnosis [from Vucetich et al. (2015a); autapomorphies marked with an asterisk]. Small to very small sized caviomorph. Brachydont cheek teeth* (see Phyloge- 
netic Analysis, below). Clearly evident cusps and thin crests separated by wide flexids. Retention of deciduous premolars throughout life. Upper molars with four straight crests (anteroloph, protoloph, metaloph, and posteroloph); anteroand posteroloph fused labially in juveniles with proto- and metaloph delimiting the antero- and metafossette, respectively. Lower molars with variably developed metalophulid II: interrupted or absent on m1-m2, absent or interrupted on m3; presence of accessory cusp on lowers molars*. Lower deciduous premolar with variably developed metalophulid II and mesolophid united with or near the metaconid. Lower incisor long, with its posterior end located posterior to m3. Well-developed masseteric crest of the mandible, mental foramen generally absent, and masseteric fossa moderately to very deep anteriorly. Skull with a moderately developed groove for the passage of the nerve infraorbitalis*.

Acarechimys minutus (Ameghino, 1887)

Figure 3.1-5

1887. Acaremys minutus Ameghino, p. 9.

2016. Ameghinomys constans Verzi, Olivares and Morgan, pp. 412-413.

Type series. MLP 15-410a, left mandible with m1-3; MACNA 237, right mandible with dp4-m3; MACN-A 238, right mandible with dp4-m3; MACN-A 4075, right mandible with dp4-m1.

Lectotype. MLP 15-410a Patterson (UMS, pers. comm.) and Pascual, 1967.

Paralectotypes. MACN-A 237, MACN-A 238, MACN-A 4075. Referred material. (Supplementary appendix 1).

Geographic and stratigraphic occurrences. Santa Cruz and Neuquén provinces, Argentina; Quebrada Honda, Bolivia. Santa Cruz Formation, late early Miocene, Santacrucian SALMA; Collon Curá Formation, early middle Miocene, Colloncuran SALMA; unnamed formation, late middle Miocene, Laventan SALMA (Supplementary appendix 1).

Emended diagnosis. Smaller than $A$. constans and A. gracilis. Upper deciduous premolar tending toward reduction and loss of the metaloph, unlike $A$. constans. Lower deciduous premolar with variably developed metalophulid II and mesolophid, a combination not present in the remaining species. Lower molars with metalophulid II reduced to a small spur on m1-2 and absent on m3, as in A. leucotheae; presence of accessory cups in m1-2 and variable presence of the posterior extension of the metalophulid I in m1-2; presence of posterior arm of the metaconid on $\mathrm{m} 1-3$, as in A. gracilis. Lower incisors laterally compressed, unlike $A$. constans and $A$. gracilis. Mandible with the notch for the insertion pars infraorbitalis of the masseter muscle (nmmpio) located below dp4-m1, unlike $A$. constans and $A$. gracilis.

Remarks. MLP 15-410a (left mandible with m1-m3) is labeled as 'lectotype' and MLP 15-410b (maxilla with right and left M1-M3) as 'type?' of Acarechimys minutus in the MLP collection. Based on the catalog information of this museum, we confirm that both specimens belong to the 'old collections', which include specimens from the expedition of C. Ameghino in 1887 and expeditions performed by other staff of the MLP in subsequent years (Vizcaíno et al., 2013). Unfortunately, the available information does not allow us to know which of these fossils were recovered by C. Ameghino (no labels or catalog written by Ameghino are available). However, according to the unpublished work of Patterson, MLP 15-410a is the lectotype of Acarechimys minutus since 'in fact the only specimen labeled as minutus or attributable to the species is M.L.P. $n^{\circ} 15-410 a$, a portion of left ramus with base of $\mathrm{I}$, roots of dm4, m1-3. This individual thus becomes the lectotype'. Thus, based on the confirmation made by Patterson, we interpret that MLP 15410a could have had a label made by F. Ameghino. On the contrary, we think that MLP 15-410b was not available for Patterson in the 1950s, since in his UMS he stated that the palatal fragment described by Ameghino for this species was lost. Only later was MLP 15-410b relocated and available for study in the MLP collections. We believe that this took place after the accession of fossils belonging to old assemblages into the MLP collections, an occurrence that has taken place many times since the 1960s (Reguero and Tonni, pers. comm., 2016). The specimen file card of MLP 15-410b includes a note by R. Pascual that it possibly corresponds to the palatal fragment used by Ameghino in 1889 for the description of Acaremys minutus (handwriting by Pascual). We agree with Pascual that this specimen matches Ameghino's description; nevertheless, there is no evidence that it was part of the collection studied by Ameghino. Therefore, we have not included MLP 15-410b among the syntypes of Acarechimys minutus. We recognize three additional specimens housed at the MACN collection as part of the original type series: MACN-A238 and MACN- 
A 4075, which are illustrated in the atlas of Ameghino (Ameghino, 1889; plate IV, figs. 22-23), and MACN-A 237, which is mentioned in the catalog of Ameghino (MACN) as being a member of the same stock as MACN-A238. In summary, we identify four fossils used by F. Ameghino to erect the species Acaremys minutus: MLP 15-410a, MACNA237, MACN-A 238, and MACN-A 4075.

Pascual (1967) stated that MLP 15-410a was the lectotype of Acarechimys minutus. Although this material corresponds to an old specimen with the occlusal surface very worn, we agree with Patterson's assignation. By default, the remaining specimens of the original type series are paralectotypes.

Based on dental morphology (symmetric absence of mure on the $\mathrm{M} 2$ delimiting an antero- and posterofossette and a relatively large and fully tetralophodont $\mathrm{M} 3$ ) we cannot assign MLP 15-410b to any recognized caviomorph species. It probably represents a new octodontoid (Arnal and Vucetich, personal observation) and will be the subject of future investigations.

Description. Both upper tooth rows are parallel to each other but are obliquely implanted with respect to the palatal plane.

The upper cheek teeth are wider than long (Tab. 1), slightly terraced, and tetralophodont. Molars have a long anteroloph that reaches the paracone and delimits an anterofossette in juvenile specimens (Fig. 3.1). The protoloph is anteriorly oblique and curved. The metaloph departs from the junction of the mure and the anterior arm of the hypocone, and its labial end, which includes the metacone, turns back to fuse with the posteroloph, delimiting a metafossette in juveniles (Fig. 3.1). The M3 has a labially placed hypocone, and a hypofossette is formed in adult specimens (Fig. 3.1). The anterofossette and metafossette are equally deep and extend further across the occlusal surface than the mesoflexus. The hypoflexus is the deepest flexus and is anteriorly oriented.

The DP4 is molarized and resembles the molars but usually differs in the presence of a reduced metaloph that does not reach the labial end of the posteroloph, by the presence of a short protoloph that does not reaches the paracone, and by a less oblique protoloph and hypoflexus (Fig. 3.1).

Upper incisors are oval in section. The anterior face is straight and the lingual face is curved.
The description of the skull is based on an almost complete skull (YPM-VPPU 15806; Fig. 3.2) and maxillary fragments (MACN-A 4070, MPM-PV 15088). The nasals extend posteriorly to the dorsal root of the zygoma. Posteriorly, the frontal bones have concave lateral margins. The premaxillae occupy the anterior half of the lateral wall of the snout (Fig. 3.2); the ascending processes of the premaxillae are slightly exposed on the skull roof and are a little longer than the nasals, unlike in Acaremys murinus, in which they are broadly exposed on the skull roof. The rostral masseteric fossa (sensu Patterson and Wood, 1982) is shallow, subtriangular, and limited ventrally by the incisor tuberosity (Fig. 3.2), unlike in Acaremys murinus, Pseudoacaremys kramarzi, and Sciamys principalis, in which the incisor tuberosity is included in the rostral masseteric fossa (Arnal and Vucetich, 2015). The dorsal root of the zygoma continues ventrally with a robust vertical ramus of the zygoma, similar to Sciamys principalis (Fig. 3.2). This vertical ramus is mainly straight, as in Prospaniomys priscus, rather than posteriorly oblique as in most octodontoids (Arnal and Kramarz, 2011). The ventral root of the zygoma extends slightly in front of the DP4 (Fig. 3.2), and its antero-posterior diameter is similar to its dorso-ventral diameter, unlike Pseudoacaremys kramarzi, where the antero-posterior diameter is twice the dorso-ventral one (Arnal and Vucetich, 2015). In ventral view, the masseteric tuberosity (for the origin of the masseter superficialis muscle, pars anterior) is conspicuous and continuous laterally with a shallow fossa for the origin of the masseter lateralis muscle. Posterior to the masseteric tuberosity is a small foramen of uncertain homology. On the dorsal face of the ventral root of the zygoma is a faint furrow for the passage of the infraorbitalis nerve. The horizontal ramus of the zygoma is high in lateral view (Fig. 3.2), unlike Prospaniomys priscus in which it is low (Arnal and Kramarz, 2011). It is formed mainly by the jugal bone, which lies at the base of the vertical ramus of the zygoma along with the maxillary bone (Fig. 3.2); this suture is straight and oblique. The paraorbital process is conspicuous and formed by the jugal and a small portion of the squamosal. The jugal fossa (for the origin of the posterior masseter muscle) is well-developed; it is antero-posteriorly long, dorso-ventrally high, and medio-laterally deep, unlike Prospaniomys priscus, in which it is short and shallow.

The diastema is longer than the tooth row and widens 
Table 1 - Acarechimys dental measurements.

\begin{tabular}{|c|c|c|c|c|c|c|c|c|c|c|}
\hline \multirow[t]{2}{*}{ A. minutus } & \multicolumn{2}{|c|}{ MACN-A 237} & \multicolumn{2}{|c|}{ MACN-A 4070} & \multicolumn{2}{|c|}{ MACN-A 4073} & \multicolumn{2}{|c|}{ MLP 15-410a } & \multicolumn{2}{|c|}{ MPM-PV 15039} \\
\hline & $a p l$ & $m w$ & $a p l$ & $m w$ & $a p l$ & $m w$ & $a p l$ & $m w$ & $a p l$ & $m w$ \\
\hline$d p 4$ & 1.62 & 1.30 & & & 1.56 & 1.18 & - & - & 1.44 & 1.22 \\
\hline$m 1$ & 1.57 & 1.52 & & & 1.46 & 1.39 & - & 1.58 & 1.48 & 1.40 \\
\hline$m 2$ & 1.58 & 1.48 & & & 1.50 & 1.49 & 1.62 & 1.62 & 1.42 & 1.38 \\
\hline$m 3$ & 1.24 & 1.40 & & & - & - & 1.56 & 1.58 & - & - \\
\hline DP4-M3 & & & 6.92 & - & & & & & & \\
\hline$D P 4$ & & & 1.62 & 1.90 & & & & & & \\
\hline M1 & & & 1.84 & 2.06 & & & & & & \\
\hline M2 & & & 1.90 & 2.10 & & & & & & \\
\hline M3 & & & 1.56 & 1.84 & & & & & & \\
\hline \multirow[t]{2}{*}{ A. constans } & \multicolumn{2}{|c|}{ MLP 15-391 } & \multicolumn{2}{|c|}{ MACN-A $247 a$} & \multicolumn{2}{|c|}{ MACN-A $247 b$} & \multicolumn{2}{|c|}{ MPM-PV 15002} & \multicolumn{2}{|c|}{ MPM-PV 15092} \\
\hline & apl & $m w$ & apl & $m w$ & $a p l$ & $m w$ & apl & $m w$ & apl & $m w$ \\
\hline$d p 4$ & 2.22 & 1.64 & - & - & 2.36 & 1.64 & - & 1.56 & 2.33 & 1.53 \\
\hline$m 1$ & 2.00 & 1.88 & 2.20 & 2.01 & 2.30 & 2.08 & 2.12 & 1.82 & 1.97 & 1.67 \\
\hline$m 2$ & 2.01 & 1.94 & 2.36 & 2.16 & 2.20 & 2.16 & - & - & 1.94 & 1.96 \\
\hline m3 & 1.92 & 1.76 & - & - & - & - & - & - & - & - \\
\hline DP4-M2 & & & & & & & 5.04 & - & & \\
\hline$D P 4$ & & & & & & & 1.46 & 1.78 & & \\
\hline M1 & & & & & & & 1.78 & 2.01 & & \\
\hline M2 & & & & & & & 1.80 & 2.20 & & \\
\hline
\end{tabular}

\begin{tabular}{lcr} 
A. leucotheae & MPEF-PV 10677 \\
\hline & $a p l$ & $m w$ \\
\hline$d p 4$ & - & 1.02 \\
$m 1$ & 1.38 & 1.34 \\
$m 2$ & 1.48 & 1.34 \\
$m 3$ & 1.20 & 1.18
\end{tabular}

\begin{tabular}{|c|c|c|c|c|c|c|c|c|c|c|}
\hline \multirow[t]{2}{*}{ A. minutissimus } & \multicolumn{2}{|c|}{$M A C N-A 258$} & \multicolumn{2}{|c|}{ MACN-A 1894} & \multicolumn{4}{|c|}{ MACN-A 12683} & \multicolumn{2}{|c|}{ MLP 15-1 } \\
\hline & $a p l$ & $m w$ & $a p l$ & $m w$ & $a p l$ & $m w$ & apl & $m w$ & $a p l$ & $m w$ \\
\hline$d p 4$ & 1.22 & 1.11 & 1.51 & 1.12 & & & 1.41 & 1.19 & 1.32 & 1.12 \\
\hline$m 1$ & 1.25 & 1.26 & 1.41 & 1.30 & & & 1.43 & 1.34 & 1.26 & 1.28 \\
\hline$m 2$ & 1.46 & 1.46 & 1.43 & 1.31 & & & 1.40 & 1.32 & 1.30 & 1.30 \\
\hline$m 3$ & 1.28 & 1.21 & 1.20 & 1.20 & & & - & - & 1.00 & 1.12 \\
\hline$D P 4-M 2$ & & & & & 3.96 & - & & & & \\
\hline$D P 4$ & & & & & 1.30 & 1.30 & & & & \\
\hline M1 & & & & & 1.28 & 1.46 & & & & \\
\hline M2 & & & & & 1.38 & 1.53 & & & & \\
\hline \multirow[t]{2}{*}{ A. gracilis } & \multicolumn{2}{|c|}{$M A C N-A$ 52-128 } & \multicolumn{2}{|c|}{ MACN-A 4060} & \multicolumn{2}{|c|}{ MACN-A 4263} & \multicolumn{2}{|c|}{ MLP 15-391a } & \multicolumn{2}{|c|}{ MPM-PV 17430} \\
\hline & $a p l$ & $m w$ & apl & $m w$ & $a p l$ & $m w$ & $a p l$ & $m w$ & $a p l$ & $m w$ \\
\hline$d p 4$ & 1.88 & 1.54 & 2.32 & 1.70 & 1.76 & 1.48 & 1.90 & 1.59 & 2.08 & 1.54 \\
\hline$m 1$ & 1.96 & 1.74 & 2.10 & 1.98 & 1.91 & 1.89 & 1.81 & 1.84 & 2.15 & 1.87 \\
\hline$m 2$ & 2.01 & 1.89 & 2.34 & 2.10 & 1.93 & 1.79 & 1.98 & 1.96 & 2.10 & 2.03 \\
\hline$m 3$ & 1.82 & 1.68 & 2.16 & 1.78 & - & - & - & - & 1.86 & 1.57 \\
\hline
\end{tabular}


(1)

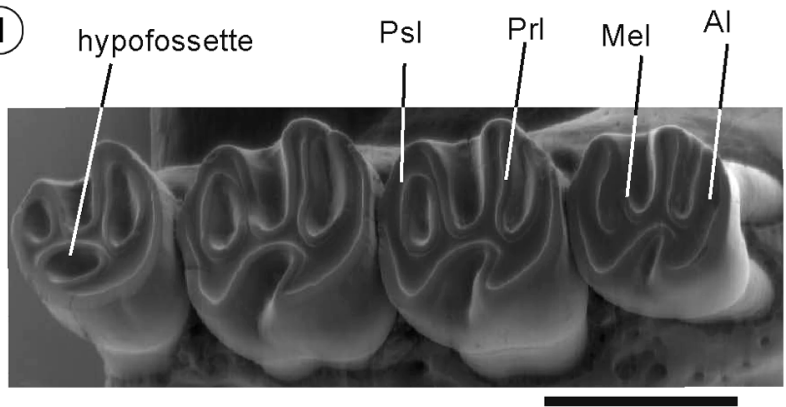

(3)

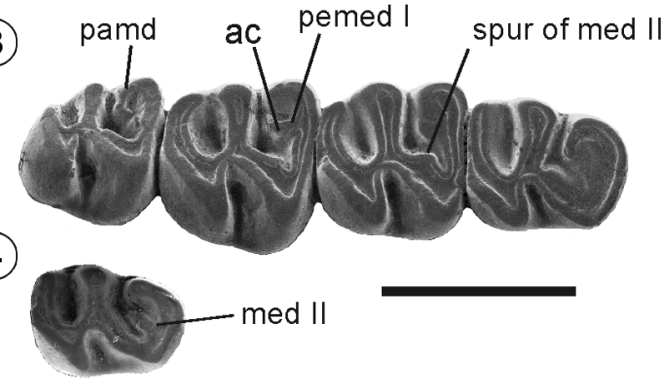

(2)
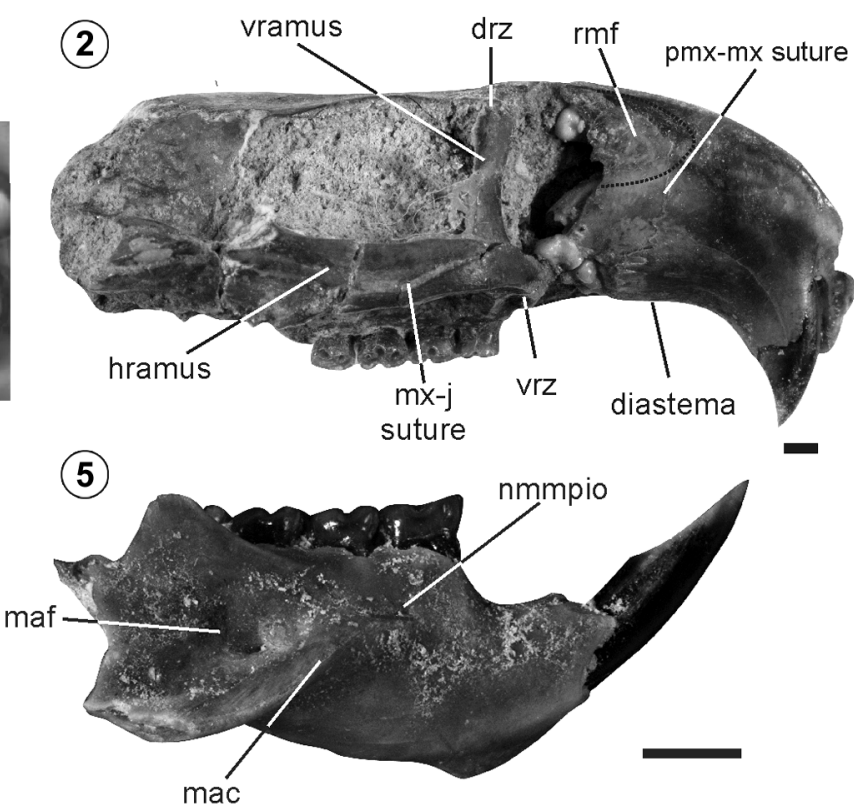

Figure 3. Acarechimys minutus; 1, MPM-PV 15088, left DP4-M3 (reversed); 2, YPM-VPPU 15806, right lateral view of the skull; 3, MACN-A 237, right dp4-m3 (paralectotype); 4, MLP 91-IX-1-97, right dp4; 5, MPM-PV 15089, external view of right mandible. Abbreviations: ac, accessory cusp; Al, anteroloph; drz, dorsal root of the zygoma; hramus, horizontal ramus of the zygoma; mac, masseteric crest; maf, masseteric fossa; Mel, metaloph; med II, metalophulid II; mx-j, maxillary-jugal; nmmpio, notch for the insertion of the masseter muscle, pars infraorbitalis; pamd, posterior arm of the metaconid; pemed I, posterior extension of the metalophulid I; pmx-mx, premaxillary-maxillary; Prl, protoloph; Psl, posteroloph; rmf, rostral masseteric fossa; vramus, vertical ramus of the zygoma; vrz, ventral root of the zygoma. Scale bars $=2 \mathrm{~mm}$.

posteriorly but is shorter than in Acaremys murinus and Pseudoacaremys kramarzi. The large incisive foramina are damaged but seem to be wider than long. Posteriorly, they are continuous with the well-developed diastemal furrows that extend to the DP4s. The posterior palatine foramina are conspicuous and located between the M1s. The openings of the posterior nares are positioned near the posterior half of the M2.

Lower cheek teeth are of similar size (Tab. 1). The dp4 is longer than wide (Fig. 3.3; Tab. 1). The metalophulid I is curved and joins the protoconid and metaconid. The ectolophid is relatively short and oblique. A short but variably developed metalophulid II extends from the postero-lingual border of the protoconid (Fig. 3.3-4) as in some specimens of $A$. minutissimus and $A$. constans. The mesolophid is also variably developed; it varies from long and fused with the metaconid (MPM-PV 15089), as in A. constans, to reduced, forming a spur of the ectolophid, as in A. gracilis (Fig. 3.3). The hypolophid is straight and merges with the entoconid. The posterolophid is long and reaches the labial side of the tooth. The anterofossettid/anteroflexid is rounded, shallow, and merged with the mesoflexid when the mesolophid is reduced (Fig. 3.3-4). The posteroflexid is closed in adult specimens. The hypoflexid is the deepest flexid and is posteriorly oblique. In adult specimens, the dp4 becomes simplified with an oval outline (MACN-A 4071).

The lower molars have three main crests; a fourth crest, second in position (metalophulid II), is variably developed (Fig. 3.3). The metalophulid I is straight, unlike in $A$. constans and $A$. gracilis, where it is curved. The metalophulid II is reduced to a spur of the ectolophid near the area of the protoconid in m1-2 and is absent in m3 (Fig. 3.3). An accessory cusp of uncertain homologies is lingually aligned with this crest and often united to the metalophulid I by a posterior extension of the metalophulid I (Fig. 3.3). The posterior arm of the metaconid is present in $\mathrm{m} 1-3$. The hypolophid and posterolophid are as in dp4. The lingual end of the posterolophid lies near the entoconid, unlike in the dp4. The antero+mesoflexid is as broad and deep as the posteroflexid.

The lower incisors are laterally compressed and long, 
extending below the tooth row to the base of the coronoid process.

The mandible is robust. The diastema is shorter than the tooth row, unlike the condition in the cranium. The diastema is concave, and the lowest part is immediately anterior to the dp4 (Fig. 3.5). A mental foramen is generally absent; when present, it is small and located below the anterior half of dp4. The nmmpio is conspicuous, antero-posteriorly long, slightly oblique, and the anterior half is located mainly below the dp4 (Fig. 3.5), as in A. minutissimus. The masseteric crest is well-developed, laterally projecting, and ventro-posteriorly oriented (Fig. 3.5). The masseteric fossa is deep in its anterior part as in A. gracilis but shallower than in species of Acaremys. This fossa is antero-dorsally limited by a faint furrow that extends from the posterior border of the nmmpio to the base of the coronoid process. The coronoid process extends postero-laterally from the $\mathrm{m} 2$ and delimits a retromolar fossa lateral to $\mathrm{m} 3$. On the lingual side of the mandible, the mandibular symphysis extends posteriorly to the posterior border of $\mathrm{m} 1$. The mandibular chin is at the level of the dp4.

Acarechimys constans (Ameghino, 1887)

Figure 4 1-4

1887. Stichomys constans Ameghino, p. 10.

2016. Acarechimys pascuali Verzi, Olivares and Morgan, partim., pp. 414-415; 417; 420.

2016. Ameghinomys constans Verzi, Olivares and Morgan, partim., pp. 412-413.

Type series. MACN-A 246, palatal fragment with left and right DP4-M2; MACN-A 247, left mandible with m1-2 and right mandible with dp4-m2;MLP 15-39, left mandible with m1-3; MLP 15-57, right mandible with m2-3 and broken m1; MLP 15-200, right mandible with dp4-m2; MLP 15-346, left mandible with dp4-m2; MLP 15-391, right mandible with dp4-m3; MLP 15-391a, right mandible with dp4-m2; MLP 15-391b, right mandible with m1-3; MLP 15-391c, left mandible with broken dp4-m1.

Lectotype. MLP 15-391 Patterson (UMS, pers. comm.) and Pascual (1967).

Paralectotypes. MACN-A 246, MACN-A 247, MLP 15-39, MLP 15-57, MLP 15-200, MLP 15-346, MLP 15-391a, MLP 15-391b, MLP 15-391c.

Referred material. (Supplementary appendix 1).
Geographic and stratigraphic occurrence. Santa Cruz Province. Santa Cruz Formation, late early Miocene, Santacrucian SALMA (Supplementary appendix 1).

Diagnosis. Larger than A. minutus, $A$. minutissimus, and $A$. leucotheae. Lower deciduous premolars with well-developed or reduced metalophulid II; mesolophid conspicuous, unlike in A. gracilis. Lower molars with metalophulid II well-developed on $\mathrm{m} 1$ and reduced or absent on $\mathrm{m} 2-3$, unlike $A$. minutus and $A$. minutissimus; accessory cusp on $\mathrm{m} 1$ variable present and conspicuous posterior arm of the metaconid absent, unlike $A$. gracilis. Lower incisors not compressed medio-laterally, unlike $A$. minutus and $A$. minutissimus. Mandible with the masseteric fossa and nmmpio located more posteriorly than in $A$. minutus, $A$. minutissimus, and $A$. leucotheae.

Remarks. We followed the same procedures as for Acarechimys minutus in identifying the original type series used by Ameghino to describe Stichomys constans. In the MLP collections, the specimen MLP 15-391 is catalogued as lectotype and MLP 15-391a, b, and c are catalogued as syntypes of Acarechimys constans. Based on the MLP catalog, we have confirmed that these specimens belong to the 'old collections' of the MLP. Patterson stated that this species was based 'on a series of incomplete mandibles in the Museo de La Plata, nos. 15-39, MLP 15-57, MLP 15200, MLP 15-346, MLP 15-391 and MLP 15-391a-d (UMS, pers. comm.). Of these, 15-391 agrees most closely with the type description and is therefore designated as the lectotype'. Thus, it is evident that these fossils were available to Patterson, who did not hesitate in considering them as part of Ameghino's original type series. Additionally, three specimens figured in Ameghino (1889 Atlas: plate VI, figs. 6-8) housed at the MACN also belong to the original type series (MACN-A 246 and MACN-A 247). Patterson (UMS, pers. comm.) stated that the palatal fragment described by Ameghino as Stichomys constans (MACN-A 246; 1889 Atlas: plate VI, fig. 8) should be referred to Adelphomys candidus Ameghino, 1887, an assignation with which we agree.

Patterson (UMS, pers. comm.) and Pascual (1967) stated that MLP 15-391 was the lectotype of Acarechimys constans. We agree with this assignation. By default, the remaining specimens of the original type series constitute the paralectotypes. Nevertheless, among the paralectotypes, MLP 15-200 has been lost since December 1978 (information 
provided by the specimen label), and we refer MLP 15-346, MLP 15-391, and MLP 15-391b to Acarechimys gracilis based on molar and mandibular morphology (see below).

Patterson (in Patterson and Wood, 1982) 'provisionally' considered Stichomys constans a synonym of Acarechimys minutissimus. However, this assignation is odd, and we think it could have been an error, since Patterson in his UMS considered Acarechimys constans as a valid species (pers. comm.). Additionally, based on its size and dental morphology, this species has traditionally been considered a distinct species (Vucetich et al., 1993a, 2010, 2015a; Kramarz, 2004; Croft et al., 2011; Arnal, 2012). Recently, Verzi et al. (2016) erected the new genus Ameghinomys to include this species (Ameghinomys constans) based on materials referred to Acarechimys minutus, Acarechimys pulchellus, Acarechimys constans, and other previously undescribed specimens. The conclusions of our systematic revision of Acarechimys differ from those of this publication. Verzi et al. (2016) associate the palatal fragment labeled as 'type?' (MLP 15-410b) of Acarechimys minutus mentioned in the previous section with the lectotype of Acarechimys constans (MLP 15-391). They argue that MLP 15-410b is proportionally larger than Acarechimys minutus, that it has a short mure comparable to the short ectolophid present in lower molars of Acarechimys constans, and that although Ameghino $(1887,1889)$ did not mention cranial fragments for Stichomys constans, he figured one in 1889 (Verzi et al., 2016). Nevertheless, the mentioned palatal fragment (Ameghino, 1889; Atlas: plate VI, fig. 8) is MACN-A 246 (Fernicola 2011, p. 52), and not MLP 15-410b as indicated by Verzi et al. (2016). Ameghino (1889) did provide the following description for Stichomys constans: ['Ia primera muela superior tiene también tres raices, como en la especie anterior (Stichomys regularis); y las cuatro muelas superiores ocupan un espacio longitudinal de 9 milimetros, como las cuatro inferiores'] ['the first upper molar also has three roots, as in the preceding species (Stichomys regularis); and the four upper cheek teeth occupy a longitudinal space of 9 millimeters, like the four lowers'] (1889, p. 247). Additionally, MLP $15-410 \mathrm{~b}$ is considerably smaller than $S$. constans [M1-3 are $6.85 \mathrm{~mm}$ long, more than $2 \mathrm{~mm}$ smaller than the value listed for Stichomys constans $(9 \mathrm{~mm})]$. Lastly, since relatively short ectolophids are common in small rodents, we do not think that the superficial resemblance to a 'short mure' on the upper molars (absent on both M2 of MLP 15-410b) can be used to refer unassociated upper and lower dentitions to the same species.

Description. As in A. minutus, both tooth rows are parallel to each other (Fig. 4.1) and are obliquely implanted labially with respect to the palatal plane. The upper cheek teeth are tetralophodont and wider than long (Fig. 4.1-2; Tab. 1). All molars and the DP4 have a subquadrangular occlusal outline. The molars have a short anteroloph that does not reach the paracone (Fig. 4.2), unlike in A. minutus, where it is long and fused with this crest. The protoloph is oblique anteriorly and curved. The metaloph is straight, departs from the junction of the mure and the anterior arm of the hypocone, and its labial end fuses with the posteroloph, delimiting a metafossette in juveniles (Fig. 4.2). The anterofossette and metafossette are equally deep and penetrate the occlusal surface slightly further than the mesoflexus. The hypoflexus is the deepest flexus and is posteriorly oriented.

The DP4 has a conspicuous metaloph, unlike in A. minutus, in which it is usually reduced (Fig. 4.2). It is fully molarized.

The description of the skull is based on MPM-PV 15002, a partial palatal fragment.

The ventral root of the zygoma extends slightly in front of the DP4 (Fig. 4.1), and its antero-posterior diameter is similar to its dorso-ventral diameter, as in A. minutus. In ventral view, the masseteric tuberosity is conspicuous. Posterior to the masseteric tuberosity is a small foramen of uncertain homology (Fig. 4.1), as in the type species. On the dorsal face of the ventral root of the zygoma is a faint furrow for the passage of the infraorbitalis nerve. In palatal view, well-developed diastemal furrows are evident that extend posteriorly to M1 (Fig. 4.1), farther than in A. minutus. The posterior palatine foramina are conspicuous and located between the M1s. The posterior nares open opposite the anterior half of the $\mathrm{M} 2$.

The dp4 is the longest tooth (Tab. 1). It has a curved metalophulid I. A well-developed (MACN-A 4058; MACN-A 4061; MACN-A 4064; MLP 15-391) (Fig. 4.3) or reduced (MACN-A 247a; MACN-A 4075) metalophulid II extends postero-lingually from the protoconid. The ectolophid is oblique and extends posteriorly from the posterior border of the protoconid. Near its posterior end, a well-developed mesolophid extends lingually and usually reaches the meta- 


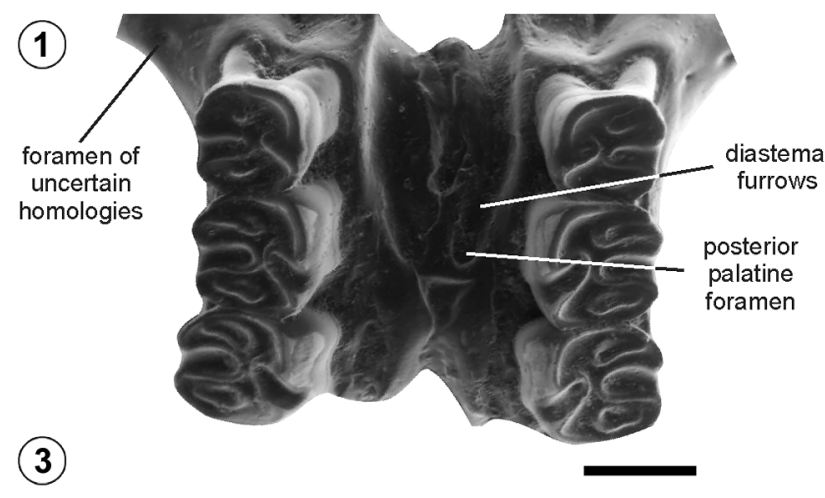

(2)

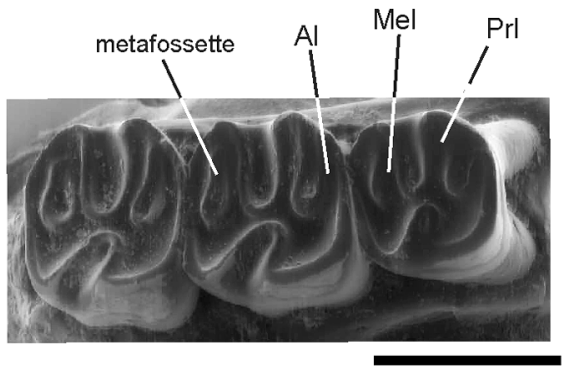

(3)
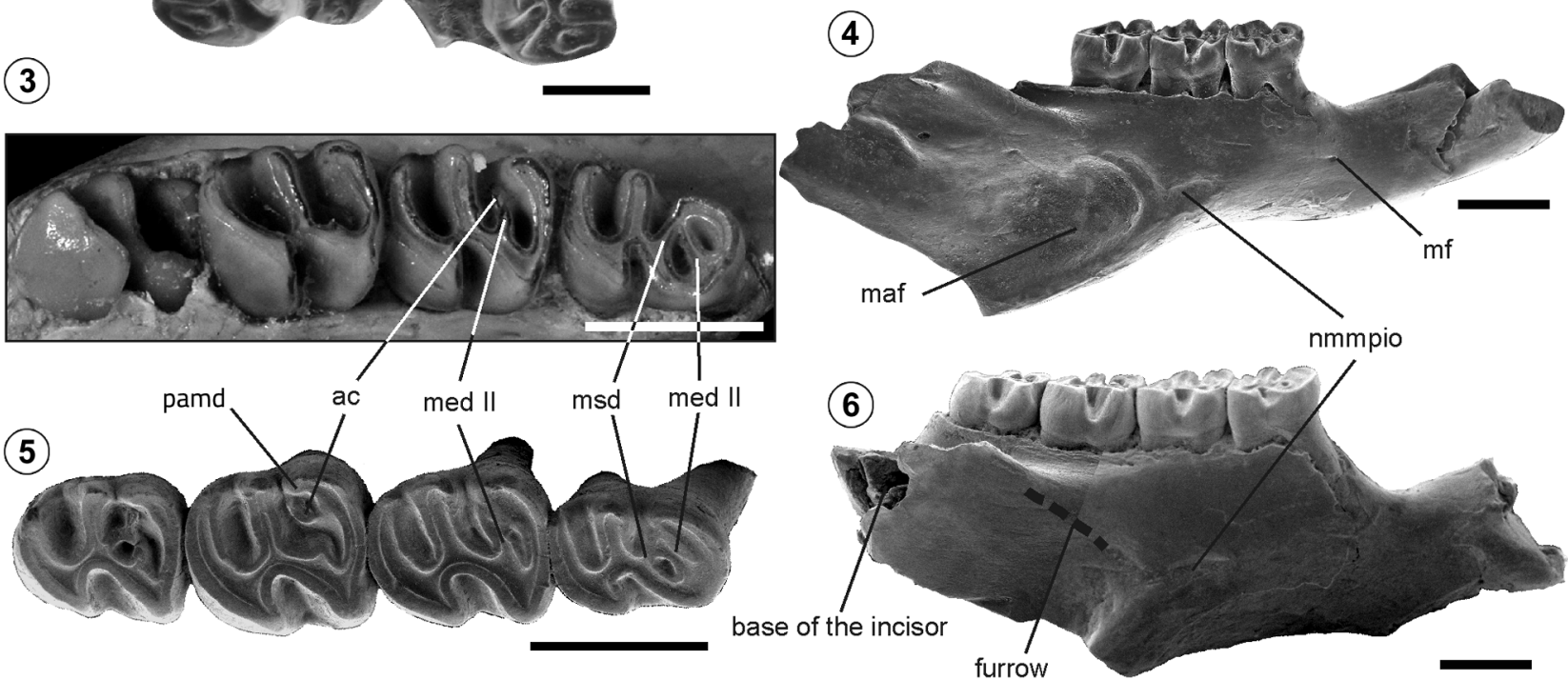

Figure 4. 1-4, Acarechimys constans; 1-2, MPM-PV 15002, palatal fragment with left and right DP4-M2; 2, left DP4-M2 (reversed); 3, MLP 15-391, right dp4-m3 (lectotype); 4, MACN-A 4064, external view of left mandible (reversed); 5-6, Acarechimys gracilis MACN-A 52-128; 5, right dp4-m3; 6, external view of the right mandible. Anterior to the right, except Figure 4.1. Abbreviations: ac, accessory cusp; Al, anteroloph; maf, masseteric fossa; med II, metalophulid II; Mel, metaloph; mf, mental foramen; msd, mesolophid; nmmpio, notch for the insertion of the masseter muscle, pars infraorbitalis; pamd, posterior arm of the metaconid; Prl, protoloph. Scale bars= $2 \mathrm{~mm}$.

conid (Fig. 4.3), as in A. minutissimus. The hypolophid is straight or curved and reaches the entoconid. The posterolophid is long, anteriorly concave, and does not contact the entoconid (Fig. 4.3). The anterofossettid is rounded and relatively shallow, the metaflexid is narrow, and the posteroflexid is the largest and deepest of the lingual flexids/ fossettids. The hypoflexid is posteriorly oriented and is deeper than the lingual flexids.

Lower molars have three main crests and a fourth, second in position, variably developed (Fig. 4.3). The metalophulid I is curved, unlike in $A$. minutus and $A$. minutissimus, where it is straight. A conspicuous metalophulid II is present in $\mathrm{m} 1$ but is reduced or absent on m2-3 (Fig. 4.3). In some cases, a labio-lingually aligned accessory cusp (Fig. 4.3) and/or a posterior extension of the metalophulid I is observed. These two structures are generally reduced or absent in m2-3. The ectolophid is generally longer than in the remaining species of the genus. The hypolophid and the posterolophid of the molars resemble the condition in the dp4. In juveniles, the hypoflexid is confluent with the posteroflexid ( $\mathrm{m} 2-3$ in Fig. 4.3). The antero+mesoflexid is as broad and deep as the posteroflexid.

Lower incisors are not laterally compressed, unlike in $A$. minutus and $A$. minutissimus. They are long, with their posterior end located at the base of the coronoid process.

The mandible has the mental foramen, when present, small and located opposite the anterior half of dp4 or slightly anteriorly (Fig. 4.4). The nmmpio is more poorly developed than the remaining species, antero-posteriorly short, and located mainly below m1 (Fig. 4.4), as in A. gra- 
cilis. The masseteric crest is well-developed and is continuous with the posterior end of the nmmpio; it extends laterally as in the remaining species of the genus. The masseteric fossa is as deep as in $A$. minutus and $A$. gracilis; it is posteriorly positioned, with its anterior border opposite $\mathrm{m} 2$ or the posterior end of $\mathrm{m} 1$ (Fig. 4.4). The furrow that delimits the masseteric fossa antero-dorsally is poorly developed. The base of the coronoid process extends anteriorly to a point between $\mathrm{m} 2$ and $\mathrm{m} 3$ (Fig. 4.4), unlike in the remaining species of the genus in which it extends to $\mathrm{m} 2$. The mandibular symphysis extends posteriorly to the level of $\mathrm{m} 1$, and a poorly developed chin is present just anterior to the anterior part of the $\mathrm{dp} 4$.

Acarechimys gracilis (Ameghino, 1891) comb. nov. Figure 4.5-6

1891. Stichomys gracilis Ameghino, p. 300.

1902. Protacaremys pulchellus Ameghino, p. 112.

2016. Acarechimys pascuali Verzi, Olivares and Morgan, partim., pp. 414-415; 417; 420.

Holotype. MACN-A 4263, left mandible with dp4-m3.

Referred material. (Supplementary appendix 1).

Geographic and stratigraphic occurrence. Chubut and Santa Cruz provinces. Sarmiento Formation, Colhué Huapi Member, early Miocene; Santa Cruz Formation, late early Miocene (Supplementary Appendix 1).

Emended diagnosis. Within the size range of $A$. constans and slightly larger than $A$. minutus. Lower deciduous premolars with well-developed metalophulid II and reduced mesolophid, unlike remaining species. Lower molars with metalophulid II poorly developed in $\mathrm{m} 1$ and reduced in m2-3; accessory cusp and posterior arm of the metaconid present, as in $A$. minutus. Lower incisors not laterally compressed, as in $A$. constans. Mandible with the nmmpio and masseteric fossa located posteriorly, unlike in $A$. minutus, A. minutissimus, and $A$. leucotheae.

Remarks. Stichomys gracilis was originally described by Ameghino (1891). Patterson (in Patterson and Wood, 1982) considered S. gracilis to be a junior synonym of Acaremys minutus, upon which he based the genus Acarechimys (Patterson and Wood, 1982). Nevertheless, we do not think that MACN-A 4263 (holotype of S. gracilis) is assignable to Acarechimys minutus; rather, it is indistinguishable from MACN-A 52-128, the holotype of Acarechimys pulchellus
(Ameghino, 1902). Thus, Acarechimys pulchellus is a junior synonym of Stichomys gracilis, and we erect the new combination Acarechimys gracilis (Ameghino, 1891).

Description. The $\mathrm{m} 2$ is the largest tooth in the dental series (Tab. 1). The dp4 has a curved metalophulid I. The ectolophid and the metalophulid II extend posteriorly from the protoconid. The metalophulid II is conspicuous and postero-lingually oblique, as in A. minutissimus and A. constans (Fig. 4.5). The mesolophid is reduced to a short spur that extends from the posterior end of the metalophulid II and delimits a fossettid (Fig. 4.5). The hypolophid is long and straight. The posterolophid is long and curved but does not contact the lingual end of the hypolophid (Fig. 4.5). The hypoflexid is the deepest flexid and is posteriorly oblique.

The lower molars have three main crests and a fourth, second in position, variably developed (Fig. 4.5). The metalophulid I is curved, as in $A$. constans. The metaconid extends posteriorly to form the posterior arm of the metaconid, which is well-developed in m1-3 (Fig. 4.5), unlike in A. constans, in which is absent. The metalophulid II is reduced but more developed in $\mathrm{m} 1$ than in $\mathrm{m} 2-3$ (Fig. 4.5). An accessory cusp is present, including in $\mathrm{m} 3$, unlike in other species of the genus (Fig. 4.5). The hypolophid and posterolophid are as in $\mathrm{dp} 4$.

The lower incisors are robust and not laterally compressed. They have a thick enamel layer, a straight lingual border, and a curved labial one. This tooth is long, as in the remaining species of the genus, with its posterior end posterior and labial to m3 (Fig. 4.6).

The mandible has a short, concave diastema, as in the remaining species (Fig. 4.6). The mental foramen is generally absent, but a very small foramen is present anterior to the dp4 in MPM-PV 17430. The nmmpio is long, conspicuous, and mostly located below m1 (Fig. 4.6). The masseteric crest is well-developed, continuous with the nmmpio, and projects laterally. The masseteric fossa is slightly deeper than in $A$. constans but shallower than in A. minutissimus (Fig. 4.6). The furrow that delimits the masseteric fossa antero-dorsally is poorly developed, as in the remaining species. The coronoid process extends anteriorly to the level of $\mathrm{m} 2$; it is postero-laterally extended and delimits a retromolar fossa lateral to $\mathrm{m} 2-3$. Its anterior border is straight, and its dorsal tip is dorsal to the cheek teeth. Posteriorly the mandibular notch is shallow. Lingually, the mandibular sym- 
physis extends posteriorly to the level of dp4; posteriorly, the mental process is moderately developed.

Acarechimys leucotheae Vucetich, Dozo, Arnal, Pérez 2015

Figure 5. 1

Type and only material. MPEF-PV 10677, left mandibular fragment with dp4-m3 and incisor.

Geographic and stratigraphic occurrence. Chubut Province, Argentina.

Upper levels of Sarmiento Formation at Cabeza Blanca, late Oligocene; Deseadan SALMA.

Diagnosis [modified from Vucetich et al. (2015a)]. Very small, within the size range of $A$. minutissimus. Cheek teeth brachydont and terraced to a greater degree than in other species of the genus. Lower molars with three crests plus a very short metalophulid II and an accessory cusp in m1-2, as in A. minutus; posterior arm of the metaconid and posterior extension of the metalophulid I absent; posterolophid more transverse than in the other species, resulting in a more open posteroflexid. Lower deciduous premolar with the ectolophid conspicuously separated from the protoconid, very oblique, and more perpendicular to the anteroposterior axis of the tooth than in the other species of the genus; metalophulid II reduced, as in some specimens of $A$. minutus and $A$. constans. Mandible with the notch for the insertion of tendon of the masseter medialis pars infraorbitalis more oblique than in the remaining species; mental foramen absent, as in $A$. minutissimus and $A$. minutus.

Remarks. This species was recently described by Vucetich et al. (2015a) based on a single specimen (Fig 5.1). No new specimens or additional information are available.

\section{Acarechimys minutissimus (Ameghino, 1887)}

Figure 5. 2-4

1891. Stichomys diminutus Ameghino, p. 300.

1894. Sciamys tenuissimus Ameghino, p. 324

Type series. MACN-A 256, left mandible with dp4-m3; MACN-A 257, left mandible with dp4-m3; MACN-A 258, right mandible with incisor and dp4-m3; MLP 15-188, left mandible with dp4-m3.

Lectotype. MLP 15-188 Patterson in Pascual, 1967.
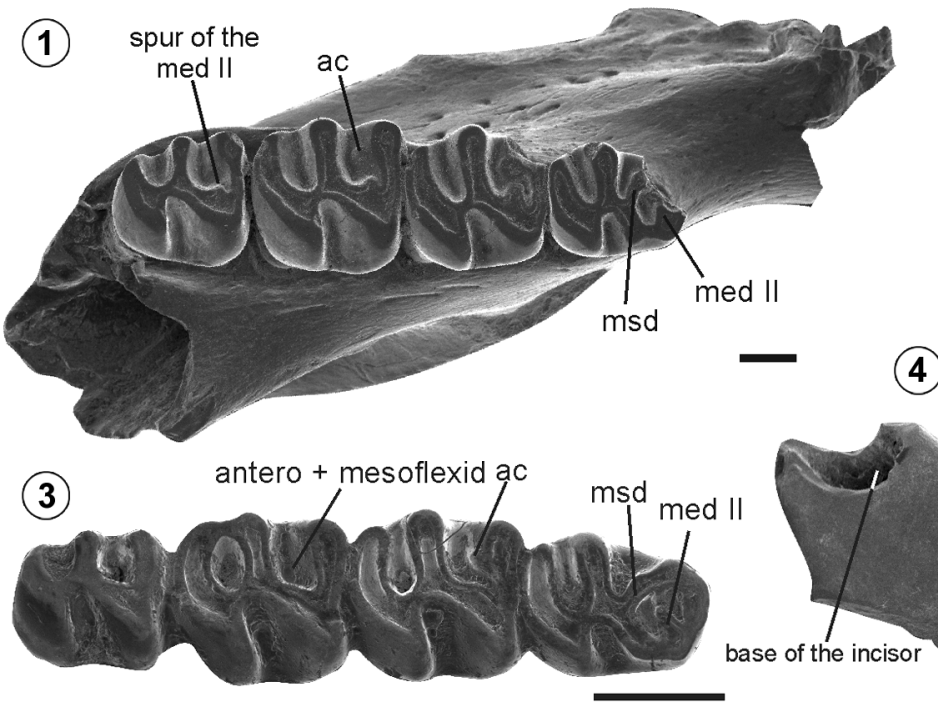

(4)

(2)
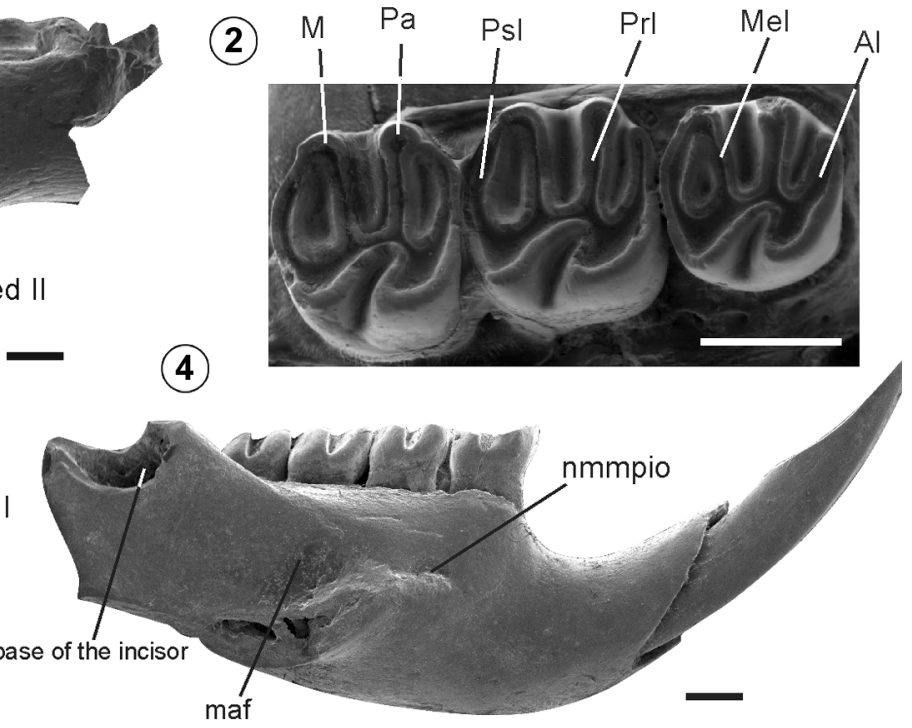

Figure 5. 1, Acarechimys leucotheae MPEF-PV 10677, left mandible with dp4-m3 (holotype; reversed); 2-4, Acarechimys minutissimus; 2, MACN-A 4076, right dp4-m3; 3, MACN-A 258, right mandible with dp4-m3 (paralectotype;); 4, MACN-A 4093, left mandible. Anterior to the right. Abbreviations: ac, accessory cusp; Al, anteroloph; M, metacone; maf, masseteric fossa; med II, metalophulid II; Mel, metaloph; msd, mesolophid; nmmpio, notch for the insertion of the masseter muscle, pars infraorbitalis; Pa, paracone; Prl, protoloph; Psl, posteroloph. Scale bars $=1 \mathrm{~mm}$. 
Paralectotypes. MACN-A 256, MACN-A 257, MACN-A 258.

Referred material. (Supplementary appendix 1).

Geographic and stratigraphic occurrence. Santa Cruz and Neuquén provinces, Argentina; La Venta, Colombia. Pinturas, Santa Cruz, and Collon Curá formations, early Miocene, late early Miocene, and middle Miocene, 'Pinturan' age, Santacrucian and Colloncuran SALMAs; Villavieja Formation, middle Miocene, Laventan SALMA (Supplementary appendix 1).

Emended diagnosis. Very small, within the size range of $A$. leucotheae. Cusps conspicuous in young specimens. Lower deciduous premolar with reduced metalophulid II and welldeveloped mesolophid, unlike the remaining species of the genus. Metalophulid II generally absent in the lower molars or present in $\mathrm{m} 1$ as a bulge into the ectolophid, unlike in the remaining species of the genus; accessory cusp in antero+mesoflexid of m1-2 variably present, and posterior arm of the metaconid and posterior extension of the metalophulid I absent, unlike in $A$. minutus. Lower incisors large relative to the mandible size. Mandible with the nmmpio straight and below dp4-m1, as in A. minutus and $A$. leucotheae.

Remarks. MLP 15-188 is labeled as the lectotype of Acarechimys minutissimus. The MLP collections include several specimens from the 'old collections' referable to $A$. minutissimus (MLP 15-1, MLP 15-188a, MLP 15-398, MLP 15408), but unfortunately the available information does not indicate whether they were collected by C. Ameghino (as is the case for $A$. minutus and $A$. constans). Patterson (UMS, pers. comm.) mentioned MLP 15-188 as the type of the species. Thus, we can infer that only MLP 15-188 was available to him. Two specimens were figured by Ameghino (1889; Atlas; plate IV, figs. 24-25). Figure 24 corresponds to MACN-A 257, but the specimen corresponding to figure 25 could not be found [Fernicola (2011) erroneously stated the reverse, that the figure 24 specimen could not be found and that figure 25 specimen is MACN-A 257]. Additionally, MACN-A 256 and MACN-A 258 are mentioned in Ameghino's catalog as belonging to the same stock as MACN-A 257. In fact, Ameghino (1889) mentioned that this species was represented by several mandibles. Thus, we conclude that four specimens (MLP 15-188, MACN-A 256, MACN-A 257, MACN-A 258) are part of the original type series used by Ameghino to erect $A$. minutissimus.
Patterson (UMS, pers. comm.) and Pascual (1967) determined MLP 15-188 to be the lectotype of the species. As a consequence, the remaining specimens of the original species are considered to be paralectotypes.

Description. Upper tooth rows labially obliquely implanted with respect to the palatal plane, as in A. minutus. Upper cheek teeth with four crests (Fig. 5.2). The M2 is slightly larger than DP4 and M1 (Tab. 1). Cusps discernable and molars slightly terraced.

The upper molars have a subquadrangular occlusal outline (Tab. 1) and well-defined paracone and metacone (Fig. 5.2). The protocone area is more rounded than in $A$. minutus. The anteroloph is short, unlike in the type species, but an anterofossette forms with little wear since the paracone does not extend very far anteriorly (M2; Fig. 5.2). The protoloph is slightly curved. The metaloph is straight and ends labially in the metacone, which is posteriorly extended and contacts the relatively short posteroloph. Consequently, the antero- and posterofossettes are delimited in juvenile specimens (Fig. 5.2). The paraflexus/fossette is the smallest and shallowest fossette, and extends across the occlusal surface as far as the mesoflexus. The hypoflexus is the deepest flexus and is anteriorly oriented.

The DP4 resembles the molars but differs in its rounded occlusal outline and in the absence of an anteriorly oriented paracone. Unlike in A. minutus, the anteroloph is short and oblique (Fig. 5.2), and in some specimens, the metaloph is reduced (MACN-A 4145), as in A. minutus.

The upper incisors are oval in section, as in $A$. minutus. The enamel is thick, and the anterior face is straight and the labial face is curved.

The skull description is based on two small, poorly preserved skull fragments (MACN-A 12683; YPM-PVPU 15178). In the ventral aspect of the skull, the incisive foramina are well-developed, as in A. minutus. Posteriorly, they are continuous with well-developed diastemal furrows that extend posteriorly to the anterior border of the DP4s. The ventral root of the zygoma extends just in front of the DP4, and its antero-posterior diameter is similar to its dorsoventral diameter, as in the type species. The masseteric tuberosity is well-developed, and the lateral furrow for the insertion of the lateral masseteric muscle is shallow. Unlike in $A$. minutus, there is no foramen of uncertain affinities posterior to the masseteric tuberosity. On the dorsal face 
of the ventral root of the zygoma is a faint furrow for the passage of the infraorbital nerve.

Lower cheek teeth in juveniles are terraced with the metaconid and entoconid higher than the protoconid and hypoconid, and adults have flat occlusal surfaces. The dp4 of this species is most variable: it has a curved metalophulid I whose lingual and labial portions can be separated from each other (MACN-A 4076; MACN-A 4083). The metalophulid II is usually reduced, as in $A$. minutus, $A$. leucotheae, and some specimens of $A$. constans (Fig. 5.3), but in some cases, it reaches the mesolophid. The ectolophid is lingually concave, and in juveniles (MACN-A 1896; MPM-PV 15098), as well as in those specimens from the Pinturas Formation, it is not connected to the protoconid. The mesolophid is always well-developed, as in $A$. constans, and reaches the metaconid to delimit an anterior fossettid (Fig. 5.3). In some cases, this crest is disconnected from the ectolophid (MACN-A 4094). The hypolophid is straight or curved, and reaches the lingual side of the tooth. The posterolophid is long and curved, unlike in A. leucotheae. The anterofossettid is rounded and shallow and disappears with the posterofossette in adults. The straight mesoflexid and the posteriorly oblique hypoflexid are the deepest flexi and remain open in adults.

The lower molars have three crests. The metalophulid II is absent or reduced to a minute bulge on $\mathrm{m} 1$ (Fig. 5.3). The metalophulid I is straight, unlike in $A$. constans and $A$. gracilis, with a labio-lingually aligned protoconid and metaconid or a metaconid that is slightly anterior to the protoconid (Fig. 5.3). The hypolophid and posterolophid are as in the dp4. Antero+mesoflexid are merged owing to the absence of metalophulid II (Fig. 5.3). An accessory cusp is usually present on $\mathrm{m} 1$ and $\mathrm{m} 2$ (Fig. 5.3). This cusp can be connected to the metalophulid I by a posterior extension of the latter (MLP 15-398). The posterior arm of the metaconid is not present. In some juvenile specimens (MACN-A 4083; MACN-A 4092; MACN-A 4093; MLP 15-398), the hypoflexid is united with the posteroflexid. Antero+mesoflexid and posteroflexid are similar in depth; the hypoflexid is the deepest flexid and is posteriorly oblique.

Lower incisors are laterally compressed and very large relative to mandible size (Fig. 5.4). The enamel layer is thick, and the anterior face is straight and the labial face is curved. The incisors are long, extending below the $\mathrm{m} 3$ and ending in a bulge on the base of the coronoid process or in a furrow in broken specimens (Fig. 5.4).

The mandible of this species has a conservative morphology that contrasts with the great variability of the lower cheek teeth. It is robust, and the diastema is dorsally concave and shorter than the tooth row as in the remaining Acarechimys species (Fig. 5.4). The mental foramen is nearly always absent (only on MACN-A 4081 is a very small foramen located anterior to the dp4). The nmmpio is straight and conspicuous, and extends below the dp4-m1 (Fig. 5.4). The masseteric crest is continuous with the posterior border of the nmmpio and protrudes laterally. The masseteric fossa is deep anteriorly, as in A. minutus (Fig. 5.4). The furrow that delimits this fossa antero-dorsally is poorly developed. The base of the coronoid process extends forward to the level of $\mathrm{m} 2$, as in $A$. minutus and $A$. gracilis, thereby delimiting a retromolar fossa lateral to $\mathrm{m} 3$. The mandibular symphysis extends posteriorly to $\mathrm{m} 1$, and a moderately developed chin is present anteriorly, which delimits the notch for the insertion of the digastric muscle.

\section{Statistical Analysis}

We tested for size differences among Acarechimys species using $\mathrm{m} 1$ and $\mathrm{m} 2$ length, as these allowed for the largest sample sizes. ANOVAs of both $\mathrm{m} 1$ length $(\mathrm{N}=69)$ and $\mathrm{m} 2$ length ( $\mathrm{N}=62$ ) were highly significant ( $<0.0001$ ). Based on Tukey's HSD (Tab. 2), two subgroups of Acarechimys are statistically distinguishable: a group of larger species consisting of $A$. constans, $A$. gracilis, and the sample from Quebrada Honda (referred here tentatively to $A$. minutus and $A$. minutissimus), and a smaller group consisting of A. leucotheae, A. minutissimus, and $A$. minutus. These size groupings are distinct in a bivariate plot of $\mathrm{m} 1 \mathrm{vs} . \mathrm{m} 2$ length (Fig. 6; $\mathrm{N}=58$ ).

Two conclusions can be drawn from this analysis. First, size does not appear to be a useful criterion for distinguishing $A$. minutissimus from $A$. minutus, even though this was the main criterion used by Ameghino (1887) for distinguishing these species. Although the smallest Acarechimys specimens do pertain to $A$. minutissimus, and $\mathrm{m} 1$ and $\mathrm{m} 2$ lengths are statistically different between these species (though only at the $p<0.05$ to 0.005 level), there is significant size overlap between larger specimens of $A$. minutissimus and smaller specimens of $A$. minutus (Fig. 6 ). 
TABLE 2 - Results of Tukey's HSD tests of mean $m 1$ length (to left of diagonal) and mean m2 length (right of diagonal) among Acarechimys samples. Only $p$-values for significant differences $(p<0.01)$ are listed.

\begin{tabular}{|c|c|c|c|c|c|c|}
\hline & $\begin{array}{l}\text { A. constans } \\
(N=11)\end{array}$ & $\begin{array}{l}\text { A. gracilis } \\
(N=13)\end{array}$ & $\begin{array}{l}\text { A. leucotheae } \\
\qquad(N=1)\end{array}$ & $\begin{array}{l}\text { A. minutissimus } \\
\qquad(N=14)\end{array}$ & $\begin{array}{l}\text { A. minutus } \\
\qquad(N=9)\end{array}$ & $\begin{array}{l}\text { Quebrada Honda } \\
\qquad(N=14)\end{array}$ \\
\hline $\begin{array}{l}\text { A. constans } \\
(N=15)\end{array}$ & - & (none) & 0.0170 & $<0.0001$ & $<0.0001$ & (none) \\
\hline $\begin{array}{l}\text { A. gracilis } \\
(N=14)\end{array}$ & (none) & - & 0.0143 & $<0.0001$ & $<0.0001$ & (none) \\
\hline $\begin{array}{l}\text { A. leucotheae } \\
(N=1)\end{array}$ & 0.0004 & 0.0014 & - & (none) & (none) & (none) \\
\hline $\begin{array}{l}\text { A. minutissimus } \\
(N=15)\end{array}$ & $<0.0001$ & $<0.0001$ & (none) & - & 0.0346 & $<0.0001$ \\
\hline $\begin{array}{l}\text { A. minutus } \\
(N=11)\end{array}$ & $<0.0001$ & $<0.0001$ & (none) & 0.0042 & - & 0.0017 \\
\hline $\begin{array}{l}\text { Quebrada Honda } \\
(N=13)\end{array}$ & 0.0047 & (none) & 0.0345 & $<0.0001$ & 0.0080 & $n / a$ \\
\hline
\end{tabular}

Abbreviations: $\boldsymbol{N}=$ number of specimens.

The single known specimen of $A$. leucotheae plots very close to this area of overlap. Acarechimys constans and A. gracilis show a pattern similar to $A$. minutissimus and $A$. minutus but with even greater size overlap (Fig. 6); the two species show virtually the same range of values for both $\mathrm{m} 1$ and $\mathrm{m} 2$ length and cannot be distinguished from one another based on size alone.

The other noteworthy result of this analysis is that the specimens in the Acarechimys sample from Quebrada Honda, tentatively identified as both $A$. minutus and $A$. minutissimus, are significantly larger than Patagonian specimens referred to these species, and similar in size to $A$. constans and $A$. gracilis (Fig. 6 ). This suggests that the Quebrada Honda populations referred to $A$. minutus and $A$. minutissimus evolved in parallel toward larger size in this region during the late middle Miocene, or that they represent different species from those from Patagonia. If the first hypothesis is correct, the differences in size could be the result of similar responses to a common environmental factor such as climate or habitat. Body size change in response to climate has been documented in other extinct species (e.g., Gingerich, 2003; Chew, 2015) and climate change has been proposed to have had a significant effect on the evolution of body size in North American Cenozoic mammals (Lovegrove and Mowoe, 2013). In this case, it is curious that the single specimen of Acarechimys from La Venta, Colombia, here referred to $A$. minutissimus, is similar in size to Pata- gonian specimens of this species $(\mathrm{m} 1$ length $=1.56 \mathrm{~mm}$; Walton, 1990, tab. 1). If climate (temperature) were primarily responsible for the larger size of Quebrada Honda specimens, one might expect a similar pattern at La Venta, which is the same age as Quebrada Honda and also located in tropical latitudes. Testing this hypothesis requires studying additional specimens of Acarechimys collected at Quebrada Honda since the publication of Croft et al. (2011)

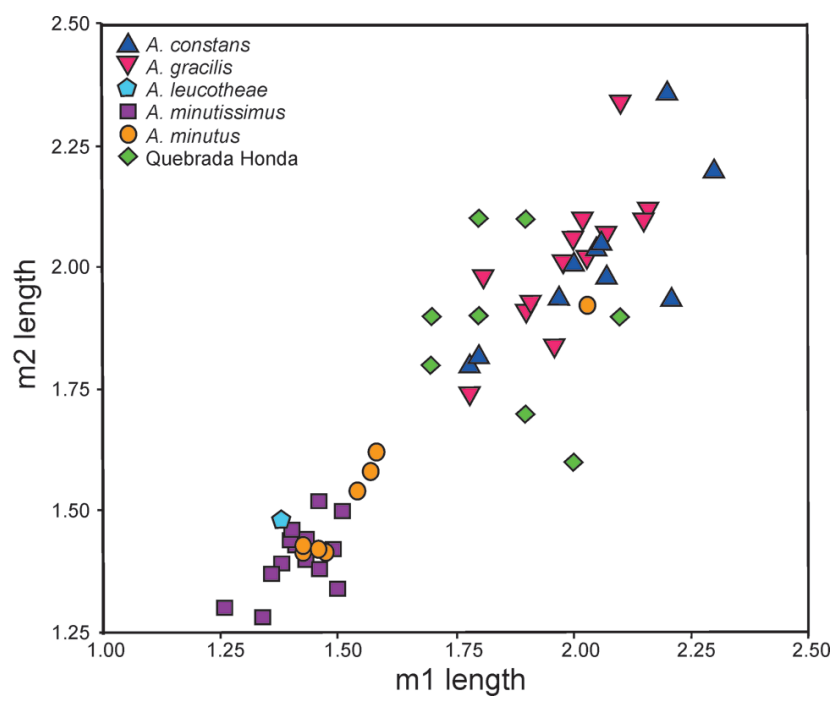

Figure 6. Bivariate plot showing the relationship between $\mathrm{m} 1$ and $\mathrm{m} 2$ length (measured in $\mathrm{mm}$ ) of the five species of Acarechimys. 
and incorporating data from ongoing paleoenvironmental studies at the site (Cadena et al., 2015; Catena et al., 2016). It should also be noted that three $A$. minutus specimens from Patagonia are particularly large and fall within the range of specimens from Quebrada Honda (the first two are repre- sented only by m1): MLP 82-XII-1-31 (Santa Cruz Province, exact provenance unknown), MLP 91-IX-1-200 (Collon Curá Formation at Cañadón del Tordillo), and MPM-PV 4193 (Puesto La Costa, costal Santa Cruz Province; Fig. 6). Each of these represents a relatively large individual within an

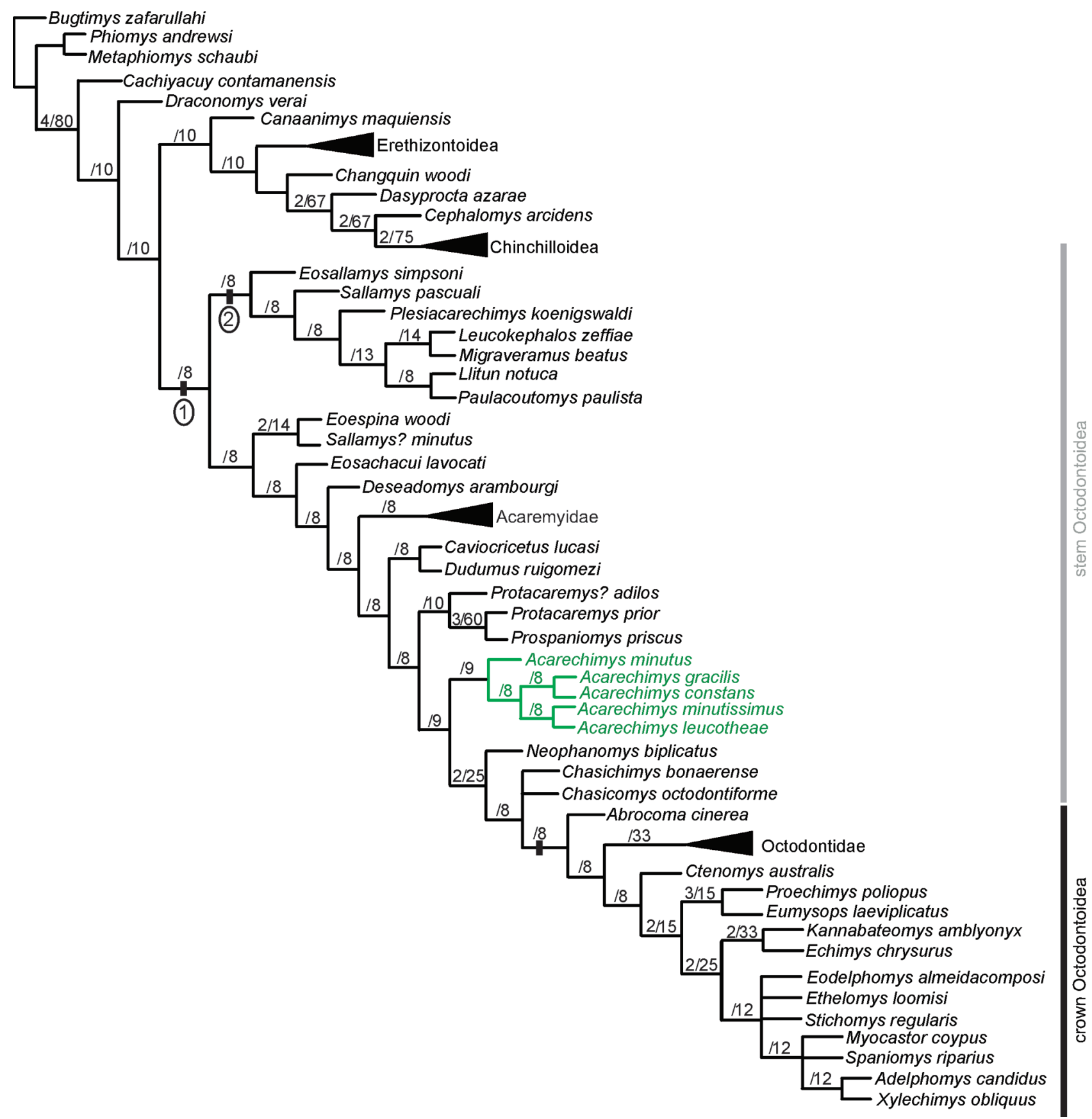

Figure 7. Consensus tree of 12 MPTs showing the phylogenetic relationships of Acarechimys species (highlighted in green). Numbers at nodes separated by slash refer to absolute (anterior) and relative (posterior) Bremer supports values (no number of absolute Bremer supports denotes 1). Numbers in circles are nodes: 1- Pan Octodontoidea, 2-Basal octodontoid clade. 
otherwise small-bodied population and provides no systematic explanation for the relatively large size of the Quebrada Honda sample.

\section{Phylogenetic Analysis}

The cladistic analysis resulted in 12 Most Parsimonious Trees (MPTs) of 798 steps each (Consistency index $=0.318$; Retention index $=0.544$ ) and the best score hit 57 times out of 1,000. The strict consensus tree (Fig. 7) has a wellresolved topology. Results are in general agreement with previous analyses, but minor differences are present with respect to the relationships of some groups. One interesting aspect is the basal position of Draconomys verai (early Oligocene of Chubut province, Argentina) within caviomorphs. The phylogenetic relationships of some species originally described as basal octodontoids (e.g., $D$. verai; Eosallamys simpsoni, Eoespina woodi, and Eosachacui lavocati from the late Eocene?-early Oligocene of Peru; Changquin woodi from the late Oligocene of Chubut province; and Dudumus ruigomezi from the early Miocene of Chubut province, Argentina) and of those taxa from the late middle Eocene of Contamana, Peru (Cachiyacuy contamanensis and Canaanimys maquiensis) are not clear and vary in different analyses (Antoine et al., 2012; Arnal et al., 2014; Arnal and Vucetich, 2015). Therefore, the relationships of these species will be the subject of a future study focused on basal caviomorphs.

Pan-Octodontoidea (node 1) is characterized by six synapomorphies [metaloph on DP4 indistinct, probably fused to the posteroloph (character 13:1); mesostyle on DP4 indistinct or absent (character 15:0); mesolophule slightly oblique on M1-M2 (character 42:1); presence of an anterior flexid in metalophulid I of $\mathrm{p} 4$ (character 70:0); short mesolophid on $\mathrm{p} 4$ (character 73:0); nmmpio at the middle of the mandible high (character111:1)]. Nevertheless, node 1 has a low support (Fig. 7), since most of those characters are scored in only a few taxa.

Within stem-Octodontoidea, several clades previously recovered in other analyses are also recovered here. Node 2 (Fig. 7) is the sister-clade to remaining octodontoids and includes Eosallamys simpsoni, Migraveramus beatus, and several other species including the enigmatic Plesiacarechimys koenigswaldi from the middle Miocene of Neuquén Province (Argentina). Later-diverging clades include (Eoespina woodi
+ Sallamys? minutus), Acaremyidae, (Caviocricetus lucasi + Dudumus ruigomezi), and the five species of Acarechimys. The phylogenetic relationships of crown Octodontoidea (Fig. 7) should be considered tentative because the taxonomic sample of this study is not focused on this part of the tree.

Acarechimys is recovered as a monophyletic genus of stem-octodontoids (Fig. 7) characterized by the presence of brachydont cheek teeth (character 3:0), the presence of an accessory cusp on m1-2 (character 97:0), and a groove for the passage of the nerve infraorbitalis (character 139:1). Acarechimys minutus, the earliest-diverging species, is distinguished by a metacone that is slightly lingual to the paracone on M2 (character 39:1). The clade of Acarechimys gracilis + A. constans is characterized by a lack of compressed lower incisors (character 101:1) and by having the nmmpio positioned beneath $\mathrm{m} 1$ (character 110:0). Its sister clade, $A$. minutissimus + A. leucotheae, is characterized by the presence of terraced occlusal surfaces in all cheek teeth (character 9:0) and a deep anterior portion of the masseteric fossa (character 113:2). A striking aspect of these results is the reacquisition of very low cheek teeth by the genus (interpreted as a reversal within octodontoids), although such a reversal has never been postulated for octodontoids. Analyses underway will further test this hypothesis. Lastly, unlike the proposal of Verzi et al. (2016) Abrocoma cinerea is not directly related to any species of Acarechimys; rather, it is the earliest-diverging crownOctodontoidea.

\section{DISCUSSION AND CONCLUSIONS}

The systematic and phylogenetic analyses performed here allow us to define the content of the Acarechimys group and to better discriminate the included species. Acarechimys is characterized by a unique mix of states that are plesiomorphic (e.g., low-crowned cheek teeth) and apomorphic (retention of the deciduous premolar, absence of mental foramen, presence of an accessory cusp on $\mathrm{m} 1-2$, and presence of a groove for the passage of the nerve infraorbitalis) among octodontoids. Additionally, Acarechimys species differ from each other by the presence/absence of dental and mandibular structures (Tab. 3). Our statistical analyses demonstrate that size is not a relevant feature for distinguishing $A$. minutus from $A$. minutissimus. Traditionally, this was the main feature used for distinguishing species, 


\begin{tabular}{|c|c|c|c|c|c|}
\hline & A. minutus & A. constans & A. gracilis & A. leucotheae & A. minutissimus \\
\hline \multicolumn{6}{|l|}{$d p 4$} \\
\hline Metalophulid II & $\begin{array}{l}\text { Variably-developed } \\
\text { (usually reduced) }\end{array}$ & $\begin{array}{c}\text { Variably-developed } \\
\text { (conspicuous or reduced) }\end{array}$ & Well-developed & Reduced & Reduced to a spur \\
\hline Mesolophid & Usually reduced & Well-developed & Reduced & Well-developed & Well-developed \\
\hline \multicolumn{6}{|l|}{$m 1$} \\
\hline Metalophulid II & Reduced & $\begin{array}{l}\text { Variably developed } \\
\text { (usually conspicuous) }\end{array}$ & Variably developed & Reduced & $\begin{array}{l}\text { Reduced to a spur } \\
\quad \text { or absent }\end{array}$ \\
\hline Pamd & Present & Absent & Present & Absent & Absent \\
\hline Pemed I & Variably Present & Variably present & Variably-developed & Absent & Absent \\
\hline Accessory cusp & Present & Variably present & Present & Present & Present/absent \\
\hline \multicolumn{6}{|l|}{$m 2$} \\
\hline Metalophulid II & Reduced & Reduced & Reduced & Reduced & Absent \\
\hline Pamd & Present & Absent & Present & Absent & Absent \\
\hline Pemed I & Variably present & Variably present & Variably present & Absent & Absent \\
\hline Accessory cusp & Present & Variably present & Present & Present & Present/absent \\
\hline \multicolumn{6}{|l|}{$m 3$} \\
\hline Metalophulid II & Absent & Reduced & Reduced/absent & Reduced & Absent \\
\hline Pamd & present & Absent & present & Absent & Absent \\
\hline Pemed I & Absent & absent & Variably present & Absent & Absent \\
\hline Accessory cusp & Absent & Variably present & Present & present & Present \\
\hline \multicolumn{6}{|l|}{ Lower incisor } \\
\hline Laterally compress & yes & no & no & - & yes \\
\hline \multicolumn{6}{|l|}{ Mandible } \\
\hline Anterior border nmmpio & Below dp 4 & Below dp4-m1 & Below dp4-m1 & Below dp 4 & Below dp 4 \\
\hline Mental foramen & Absent & Usually absent & Usually absent & Absent & Absent \\
\hline
\end{tabular}

albeit tentatively (Vucetich et al., 1993a), but our metric analyses demonstrate that there are significant overlaps in size among specimens referred to these species (see above; Fig. 5).
The temporal and geographic distributions of Acarechimys species suggests that the genus could have evolved in Patagonia by at least the early late Oligocene (in the first Patagonian radiation event; Arnal and Vucetich, 2015). 
The geologically oldest species is the minute Acarechimys leucotheae, which has only been identified at the late Oligocene (Deseadan SALMA) site of Cabeza Blanca, in Chubut Province, Argentina (Fig. 2). Cabeza Blanca has produced the greatest diversity of late Oligocene rodents in South America, nearly three times as many species as any other site of this age (Vucetich et al., 2015a). This is likely due, at least in part, to the large number of rodent specimens that have been collected there and the thorough taxonomic investigations that have focused on this site (see Wood and Patterson, 1959; Vucetich et al., 2015a), though only a single specimen of $A$. leucotheae has been identified from the site thus far. This suggests that Acarechimys was relatively rare at that time, a conjecture that is supported by the absence of specimens referable to the genus from La Flecha, the other rich Patagonian locality. Nevertheless, it is noteworthy that no specimens of Acarechimys have yet been identified from Salla, Bolivia, which has also produced a rather diverse and rich fauna of late Oligocene rodents (Lavocat, 1976; Patterson and Wood, 1982; Vucetich, 1991). Thus, the present evidence suggests that Acarechimys could have originated in Patagonia.

Acarechimys apparently continued to be rare prior to the late early Miocene, as Acarechimys gracilis, from the Colhuehuapian SALMA of Chubut Province (Fig. 2), is known only through one specimen, the holotype of Protacaremys pulchellus (Ameghino, 1902; Vucetich et al., 2010). Kramarz et al. (2004) mentioned the presence of Acarechimys for the Colhuehuapian beds of Chichinales Formation in Río Negro (Fig. 2), but we have studied this specimen and determined that it does not belong to Acarechimys. Despite the rich octodontoid fossil record and the great morphological disparity of this group prior to the late early Miocene, Acarechimys remained poorly diversified during this interval (about half of Colhuehuapian caviomorphs are octodontoids; Vucetich et al., 2010, 2015b).

By the late early Miocene, $A$. minutissimus is recorded for the 'Pinturan' age of Santa Cruz Province (Fig. 2) (Kramarz, 2004; see Kramarz and Bellosi, 2005 and Perkins et al., 2012 for a discussion about the overlap of some parts of the 'Pinturan' and Santacrucian levels). The acme of the genus was during the Santacrucian SALMA (Santa Cruz Formation), where four of the five recognized species lived in what is today Argentinean Santa Cruz Province ( $A$. minutus, A. constans, A. gracilis, and A. minutissimus). This great diversity could partly be attributable to the fact that the Santa Cruz Formation exposures have a wide distribution (Fig. 2), and have been broadly prospected since the nineteenth century, resulting in an unparalleled collection of fossils (Ameghino, 1887, 1889; Scott, 1905; Vizcaíno et al., 2012; Fernicola et al., 2014). Acarechimys has also been recovered at other Santacrucian localities in Chile (Flynn et al., 2002, 2008; Croft et al., 2007), but these materials have not yet been figured nor described in detail. In general, Santacrucian caviomorphs are quite distinct from those of the Colhuehuapian and also from those of the 'Pinturan' age (Vucetich et al., 2015b), exhibiting a marked tendency toward increased hypsodonty (Kramarz, 2001; Pérez and Vucetich, 2012; Arnal and Pérez, 2013). This ecological shift in rodents is generally thought to be a consequence of climatic deterioration in Patagonia between Colhuehuapian and Santacrucian intervals (Vucetich, 1986; Pérez and Vucetich, 2012; Arnal and Pérez, 2013). However, the evidence for such deterioration is equivocal. Global temperatures remained relatively stable across this interval (Zachos et al., 2008), and open habitats were present at least episodically during both the Colhuehuapian and Santacrucian SALMAs (Dunn et al., 2015), though arid-adapted shrubs only became dominant in Patagonia after the late Miocene (Palazzesi and Barreda, 2012). Kay et al. (2012) interpreted the paleoenvironment of coastal Santa Cruz as highly seasonal with a mosaic of vegetation including both forested and more open areas. It is possible that an increase in exogenous grit, such as volcanic ash, may have driven the trend toward increased hypsodonty and a replacement of caviomorph species across this interval, but it is difficult to test such a hypothesis at present due to a paucity of studies that include data from both the Colhuehuapian and Santacrucian SALMAs. Regardless of the precise causes of the ecological shifts in other rodents, Acarechimys is noteworthy in being the only octodontoid lineage that retained generalized, brachydont cheek teeth into the late early Miocene in high latitudes.

The Patagonian fossil record is scarce for the middle Miocene, and known fossil sites have a more northerly location compared to the early Miocene (Pascual and Odre- 
man Rivas, 1971; Pascual and Ortiz Jaureguizar, 1990; Pérez, 2010; Arnal and Pérez, 2013). Rodents are represented in few Colloncuran localities (Colloncuran SALMA; earliest middle Miocene) in Neuquén and Río Negro provinces (e.g., Cañadón del Tordillo and Pilcaniyeu Viejo respectively; Bondesio et al., 1980; Vucetich et al., 1993a; Fig. 2). During the Mayoan (latest middle Miocene), rodents have been reported from several small faunules in western Chubut and Santa Cruz provinces (Kraglievich, 1930; Bondesio et al., 1980; Vucetich and Pérez, 2011; Pérez et al., 2016), as well as the locality of El Petiso in Chubut Province, whose age is estimated to be post-Colloncuran (Villafañe et al., 2008; Arnal and Pérez, 2013). Among these middle Miocene localities, Acarechimys has only been identified at Cañadón del Tordillo and Estancia Collon Curá. In a recent preliminary revision of unpublished caviomorphs of Cañadón del Tordillo and Estancia Collon Curá, a very high octodontoid diversity was identified (Vucetich and Arnal, pers. obs.). However, Acarechimys diversity appears to be lower than during the Santacrucian. During this time, northern Patagonia experienced a short period of regreening; forests and more humid conditions are inferred for Cañadón del Tordillo based on the presence of monkeys and a high diversity of porcupines (Candela, 2003; Dunn et al., 2015; Vucetich et al., 2015b), as well as many low-crowned octodontoids (Vucetich and Arnal, pers. obs.). Few late Miocene sites are known from Patagonia. These have yielded only fragmentary remains of rodents and no octodontoids (Pascual and Bondesio, 1985; Vucetich et al., 2005; Dozo et al., 2010).

A variety of fossil sites are known from central and northern Argentina and lower latitudes of the continent during the Eocene to Miocene interval. Sites of Eocene and Oligocene age are known from Peru, Bolivia, Brazil, and Uruguay. In general, the fossil record of these localities (with the exception of Salla, Bolivia) is very poor, and no Acarechimys or closely similar taxa have been described (Lavocat, 1976; Mones and Castiglioni, 1979; Patterson and Wood, 1982; Vucetich, 1991; Vucetich et al., 1993b; Bond et al., 1998; Vucetich and Ribeiro, 2003; Frailey and Campbell, 2004; Antoine et al., 2012). An unidentified species of Acarechimys was mentioned for the late early Miocene of Chucal, northern Chile ( $18^{\circ} \mathrm{S}$; Croft et al., 2007), and the genus has been recorded at the late middle Miocene of La Venta, Colombia ( $3^{\circ} \mathrm{N}$; Walton, 1997), Quebrada Honda, Bolivia ( $22^{\circ}$ S; Croft et al., 2011), and the Fitzcarrald Arch in Peruvian Amazonia ( 11 ${ }^{\circ} \mathrm{S}$; Tejada-Lara et al., 2015: fig. 9N) (Fig. 2). Other early and middle Miocene localities have yielded remains of caviomorphs, but there is no record of Acarechimys (e.g., Madre de Dios Subandean Zone, Peru; Antoine et al., 2013). For the late Miocene, Campbell et al. (2006) mentioned the possible presence of Acarechimys in the Madre de Dios Formation in the Amazonia region, and Antoine et al. (2016) did the same for the Pebas Formation of Peru. Based on our firsthand study of the material of the Madre de Dios Formation and examination of photos of specimens from the Pebas Formation, we do not believe Acarechimys occurs at these sites. Instead, the specimens from the Amazonia region represent a new caviomorph species that is broadly represented in southwest Amazonia (Brazil and Peru) during the late Miocene (Vucetich et al., in prep). The phylogenetic relationships of this new taxon relative to Acarechimys will be the subject of future research.

Based on available evidence, Acarechimys was apparently not present in lower latitudes of the continent (north of $35^{\circ}$ S) before the early Miocene; the factors favoring its dispersal after this time remain to be elucidated. The change in its distribution toward low latitudes after the early middle Miocene is broadly reminiscent of a pattern of range contraction seen in several other groups of mammals including vermilinguan xenarthrans, platyrrhine primates, and astrapothere ungulates (Pascual et al., 1996; Ortiz Jaureguizar and Cladera, 2006; Croft et al., 2016), and it raises the possibility of a common environmental or ecological cause. Paleoecological studies of Acarechimys are necessary to provide additional insights into how and why this tiny caviomorph was able to achieve the widest temporal and geographic distribution of any caviomorph genus, while retaining a persistently brachydont dentition.

\section{AKNOWLEDGMENTS}

We are grateful to A. Kramarz (MACN), M. Reguero, M. De los Reyes, and A. Scarano (MLP-PV), F. Anaya (UATF), and Dirección de Patrimonio Cultural and MPM-PV for providing access to specimens under their care; the photographer of the MLP, B. Pianzola, for assistance photographing specimens; to $\mathrm{M}$. Reguero and $\mathrm{E}$. Tonni (MLP) for discussion of possible locations of Ameghino's fossils; to D. Brinkman and N. Upham, Division of Vertebrate Paleontology of the Peabody Museum of Natural History, Yale University, New 
Haven, Connecticut, USA for kindly providing photographs of YPMVPPU 15806 (photographed by Jamie Henderson); to Servicio de Microscopía Electrónica y Microanálisis (SeMFi-LIMF) -Facultad de Ingeniería, UNLP, Argentina; to M. E. Pérez, L. Marivaux, and A. Otero for their valuable comments that improved the final version of the manuscript. This is a contribution to the projects PICT 20142734 (MA), PICT 2012-1483 and UNLP 11/N674 (MGV), NSF EAR 958733 and EAR 1423058 (DAC), PIP 781 and UNLu CCD-CD: 054/12 (JCF), PICT 2013-0389 and UNLP 11/N750 (SFV).

\section{REFERENCES}

Ameghino, F. 1887. Enumeración sistemática de las especies de mamíferos fósiles coleccionadas por Carlos Ameghino en los terrenos eocenos de la Patagonia austral. Boletín del Museo de La Plata 1: 1-26.

Ameghino, F. 1889. Contribución al conocimiento de los mamíferos fósiles de la República Argentina. Actas de la Academia Nacional de Ciencias en Córdoba 6: 1-1027.

Ameghino, F. 1891. Nuevos restos de mamíferos fósiles descubiertos por Carlos Ameghino en el Eoceno inferior de la Patagonia austral. Especies nuevas, adiciones y correcciones. Revista Argentina de Historia Natural 1: 289-328.

Ameghino, F. 1894. Enumération synoptique des espéces des mammiferes fósiles des formations éocenes de Patagonie. Boletín de la Academia Nacional de Ciencias de Córdoba 13: 259-452.

Ameghino, F. 1902. Première contribution à la connaissance de la faune mammalogique des couches à Colpodon. Boletín de la Academia Nacional de Ciencias en Córdoba 17: 71-138.

Antoine, P.-O., Marivaux, L., Croft, D.A., Billet, G., Ganerod, M., Grégory Fanjat, C., Rousse, S., and Salas-Gismondi, S. 2012. Middle Eocene rodents from Peruvian Amazonia reveal the pattern and timing of caviomorph origins and biogeography. Proceedings of the Royal Society B 279: 1319-1326.

Antoine, P.-O., Roddaz, M., Brichau, S., Tejada-Lara, J., Salas-Gismondi, R., Altamirano, A., Louterbach, M., Lambs, L., Otto, T., and Brusset, S. 2013. Middle Miocene vertebrates from the Amazonian Madre de Dios Subandean Zone, Perú. Journal of South American Earth Sciences 42: 91-102.

Antoine, P.-O., Abello, M.A., Adnet, S., Altamirano Sierra, A.J., Baby, P., Billet, G., Boivin, M., Calderón, Y., Candela, A., Chabain, J., Corfu, F., Croft, D.A., Ganerod, M., Jaramillo, C., Klaus, S., Marivaux, L., Navarrete, R.E., Orliac, M.J., Parra, F., Pérez, M.E., Pujos, F., Rage, J.-C., Ravel, A., Robinet, C., Roddaz, M., Tejada-Lara, J., Vélez-Juarbe, J., Wesselingh, F.P., and Salas-Gismondi, R. 2016. A 60-million-year history of western Amazonian ecosystems in Contamana, eastern Peru. Gondwana Research 31: 30-59.

Arnal, M. 2012. [Sistemática, filogenia e historia evolutiva de roedores Octodontoidea (Caviomorpha, Hystricognathi) del Oligoceno tardíoMioceno medio vinculados al origen de la familia Octodontidae. Tesis doctoral, Facultad de Ciencias Naturales y Museo, Universidad Nacional de La Plata, La Plata, 317 p. Unpublished.].

Arnal, M., and Kramarz, A.G. 2011. First complete skull of an octodontoid (Rodentia, Caviomorpha) from the early Miocene of South America and its bearing in the early evolution of Octodontoidea. Geobios 44: 435-444.

Arnal, M., and Perez, M.E. 2013. A new acaremyid rodent (Hystricognathi, Octodontoidea) from the middle Miocene of Patagonia (South America) and considerations on the early evolution of Octodontoidea. Zootaxa 3616: 119-134.

Arnal, M., Kramarz, A.G., Vucetich, M.G., and Vieytes, C.E. 2014. A new early Miocene octodontoid rodent (Hystricognathi, Caviomorpha) from Patagonia (Argentina) and a reassessment of the early evolution of Octodontoidea. Journal of Vertebrate
Paleontology 34: 397-406.

Arnal, M., and Vucetich, M.G. 2015. Main radiation events in PanOctodontoidea (Rodentia, Caviomorpha). Zoological Journal of the Linnean Society 175: 587-606.

Bond, M., López. G., Reguero, M., Scillato-Yané, G.J., and Vucetich, M.G. 1998. Los mamíferos de la Fm. Fray Bentos (Oligoceno superior?) de las provincias de Corrientes y Entre Ríos, Argentina. Asociación Paleontológica Argentina, Publicación Especial 5: 41-50.

Bondesio, P., Rabassa, J., Pascual, R., Vucetich, M.G., and ScillatoYané, G.J. 1980. La Formación Collón Curá de Pilcaniyeu Viejo y sus alrededores (Río Negro, República Argentina). Su antigüedad y las condiciones ambientales según su distribución, su litogénesis y sus vertebrados. $2^{\circ}$ Congreso Argentino de Paleontología y Bioestratigrafía y $1{ }^{\circ}$ Congreso Latinoamericano de Paleontología (Buenos Aires), Actas 3: 85-99.

Bowditch, T.E. 1821. An analysis of the natural classifications of Mammalia for the use of students and travelers. Smith, Paris, $115 \mathrm{p}$.

Bremer, K. 1994. Branch support and tree stability. Cladistics 10: 295-304.

Cadena, E.A., Anaya, F., and Croft, D.A. 2015. Giant fossil tortoise and freshwater chelid turtle remains from the middle Miocene, Quebrada Honda, Bolivia: Evidence for lower paleoelevations for the southern Altiplano. Journal of South American Earth Sciences 64: 190-198.

Campbell Jr., K.E., Frailey, C.D., and Romero-Pittman, L. 2006. The Pan-Amazonian Ucayali Peneplain, late Neogene sedimentation in Amazonia, and the birth of the modern Amazon River system. Palaeogeography, Palaeoclimatology, Palaeoecology 239: 166-219.

Candela, A.M. 2003. A new porcupine (Rodentia, Hystricognthi, Erethizontidae) from the early and Middle Miocene of Patagonia. Ameghiniana 40: 483-494.

Candela, A.M., and Rasia, L.L. 2012. Tooth morphology of Echimyidae (Rodentia, Caviomorpha): homology assessments, fossils and evolution. Zoological Journal of the Linnean Society 164: 451-480.

Catena, A.M., Saylor, B., and Croft, D.A. 2016. Using ichnofossils and paleosols to reconstruct the middle Miocene paleoenvironment of Quebrada Honda, Bolivia. Journal of Vertebrate Paleontology, SVP Program and Abstracts Book 2016: 112-113.

Chew, A.E. 2015. Mammal faunal change in the zone of the Paleogene hyperthermals ETM2 and H2. Climate of the Past 11: $1223-1237$.

Croft, D.A., Flynn J.J., and Wyss, A.R. 2007. A new basal glyptodontid and other Xenarthra of the early Miocene Chucal fauna, northern Chile. Journal of Vertebrate Paleontology 27: 781-797.

Croft, D.A., Chick, J.M.H, and Anaya, F. 2011. New middle Miocene caviomorph rodents from Quebrada Honda, Bolivia. Journal of Mammalian Evolution 18: 245-268.

Croft, D.A., Carlini, A.A, Ciancio, M.R., Brandoni, D., Drew, N.E., Engelman, R.K., and Anaya, F. 2016. New mammal faunal data from Cerdas, Bolivia, a middle-latitude Neotropical site that chronicles the end of the Middle Miocene Climatic Optimum in South America. Journal of Vertebrate Paleontology. doi: 10.1080/02724634.2016.1163574.

Dozo, M.T., Bouza, P., Monti, A., Palazzesi, L., Barreda, V., Massaferro, G., Scasso, R.A., and Tambussi, C.P. 2010. Late Miocene continental biota in Northeastern Patagonia (Península Valdés, Chubut, Argentina). Palaeogeography, Palaeoclimatology, Palaeoecology 297: 100-109.

Dunn, R.E., Strömberg, C.A.E., Madden, R.H., Kohn, M.J., and Carlini, A.A. 2015. Linked canopy, climate, and faunal change in the Cenozoic of Patagonia. Science 347: 258-261. 
Esteban, G., Nasif, N., and Georgieff, S.M. 2014. Cronobioestratigrafía del Mioceno tardío-Plioceno temprano, Puerta de Corral Quemado y Villavil, provincia de Catamarca, Argentina. Acta Geológica Lilloana 26: 165-192.

Fernicola, J.C. 2011. Implicancias del conflicto Ameghino-Moreno sobre la colección de mamíferos fósiles realizada por Carlos Ameghino en su primera exploración al río Santa Cruz, Argentina. Revista del Museo Argentino de Ciencias Naturales 13: 41-57.

Fernicola, J.C., Cuitiño, J.I., Vizcaíno, S.F., Bargo, M.S., and Kay, R.F. 2014. Fossil localities of the Santa Cruz Formation (Early Miocene, Patagonia, Argentina) prospected by Carlos Ameghino in 1887 revisited and the location of the Notohippidian. Journal of South American Earth Sciences 52: 94-107.

Flynn, J.J., Novacek, M.J., Dodson, H.E., Frassinetti, D., McKenna, M.C, Norell, M.A., Sears, K.E., Swisher III, C.C., and Wyss, A.R. 2002. A new fossil mammal assemblage from the southern Chilean Andes: implications for geology, geochronology, and tectonics. Journal of South American Earth Sciences 15: 285-302.

Flynn, J.J., Charrier, R., Croft, D.A., Gans, P.B., Herriot, T.M., Wertheim, J.A., and Wyss, A.R. 2008. Chronologic implications of new Miocene mammals from the Cura-Mallin and TrapaTrapa formations, Laguna del Laja area, South Chile. Journal of South American Earth Sciences 26: 412-423.

Frailey, C.D., and Campbell, K.E. 2004. Paleogene rodents from Amazonian. In: K.E. Campbell Jr. (Ed.), The Paleogene Mammalian Fauna of Santa Rosa, Amazonian Peru. Natural History Museum of Los Angeles County, Los Angeles, p. 71-130.

Gingerich, P.D. 2003. Mammalian responses to climate change at the Paleocene-Eocene boundary: Polecat Bench record in the northern Bighorn Basin, Wyoming. Geological Society of America Special Paper 369: 463-478.

Goloboff, P.A., and Farris, J.S. 2001. Methods for quick consensus estimation. Cladistics 17: 25-34.

Goloboff, P.A., and Catalano, S.A. 2016. TNT version 1.5, including a full implementation of phylogenetic morphometrics. Cladistics 32: 221-238.

Kay, R.F., Vizcaíno, S.F., and Bargo, M.S. 2012. A review of the paleoenvironment and paleoecology of the Miocene Santa Cruz Formation. In: S.F. Vizcaíno, R.F. Kay, and M.S. Bargo (Eds.), Early Miocene Paleobiology in Patagonia: High-Latitude Paleocommunities of the Santa Cruz Formation. Cambridge University Press, Cambridge, p. 331-365.

Kraglievich, L. 1930. La Formación Friaseana del río Frías, río Fénix, Laguna Blanca, etc. y su fauna de mamíferos. Physis 10: 127-161.

Kraglievich, J. L. 1965. Speciation phyletique dans les rongeurs fossiles du genre Eumysops Ameghino (Echimyidae, Heteropsomyinae). Extrait de Mammalia 29: 258-267.

Kramarz, A.G. 2001. Un nuevo roedor Adelphomyinae (Hystricognathi, Echimyidae) del Mioceno medio inferior de Patagonia, Argentina. Ameghiniana 38: 163-168.

Kramarz, A.G. 2004. Octodontoids and erethizontoids (Rodentia, Hystricognathi) from the Pinturas Formation, Early-Middle Miocene of Patagonia, Argentina. Ameghiniana 41: 199-216.

Kramarz, A.G., and Bellosi, E.S. 2005. Hystricognath rodents from the Pinturas Formation, Early-Middle Miocene of Patagonia, biostratigraphic and paleoenviromental implications. Journal of South American Earth Sciences 18: 199-212.

Kramarz, A.G., Bellosi, E.S., Ribeiro, A.M., and Ortiz, R. 2004. Nuevos registros de vertebrados fósiles de la Formación Chichinales, Mioceno Temprano de la provincia de Río Negro, Argentina. Ameghiniana 41: 53R.

Lavocat, R. 1976. Rongeurs caviomorphes de l'Oligocene de Bolivia. II, Rongeurs du bassin Deseadien de Salla-Luribay. Palaeover- tebrata 7: 15-90.

Lovegrove, B.G., and Mowoe, M.O. 2013. The evolution of mammal body sizes: responses to Cenozoic climate change in North American mammals. Journal of Evolutionary Biology 26: 13171329.

Marivaux, L., Vianey-Liaud, M., Welcomme, J.-L., and Jaeger, J.-J. 2002. The role of Asia in the origin and diversification of histricognathous rodents. Zoologica Scripta 31: 225-239.

Mones, A., and Castiglioni, L.R. 1979. Addition to the knowledge on fossil rodents of Uruguay (Mammalia, Rodentia). Palaeöntologische Zeitschrift 53: 77-87.

Negri, F.R., Bocquetin-Villaneuva, J., Ferigolo, J., and Antoine, P.-O. 2010. Cenozoic development of terrestrial and aquatic biota: insights from the fossil record. In: C. Hoorn, and F.P. Wesselingh (Eds.), A review of Tertiary mammal faunas and birds from western Amazonia. Amazonia, Landscape and Species Evolution, A Look into the Past. Blackwell Publishing, Chichester, p. 245-258.

Olson, E.C. 1985. Bryan Patterson March10, 1909-December 1, 1979. Biogeographical Memoirs National Academy of Sciences 55: 435-450.

Ortiz Jaureguizar, E. and Cladera, G.A. 2006. Paleoenvironmental evolution of southern South America during the Cenozoic. Journal of Arid Environments 66: 498-532.

Palazzesi, L., and Barreda, V. 2012. Fossil pollen records reveal a late rise of open-habitat ecosystems in Patagonia. Nature communications 3: 1294.

Pascual, R. 1967. Los roedores Octodontoidea (Caviomorpha) de la Formación Arroyo Chasicó (Plioceno inferior) de la provincia de Buenos Aires. Revista del Museo de La Plata 35: 259-282.

Pascual, R., and Bondesio, P. 1985. Mamíferos terrestres del Mioceno medio-tardío de las cuencas de los ríos Colorado y Negro (Argentina): evolución ambiental. Ameghiniana 22: 133-145.

Pascual, R., and Odreman Rivas, O.E. 1971. Evolución de las comunidades de los vertebrados del Terciario argentino; los aspectos paleozoogeográficos y paleoclimáticos relacionados. Ameghiniana 8: 372-412.

Pascual, R., and Ortiz-Jaureguizar, E. 1990. Evolving climates and mammal faunas in Cenozoic South America. Journal of Human Evolution 19: 23-60.

Pascual, R., Ortiz-Jaureguizar, E., and Prado, J.L. 1996. Land mammals: paradigm of Cenozoic South American geobiotic evolution. In: G. Arratia (Ed.), Contribution of Southern South America to Vertebrate Paleontology. Münchner Geowissenschaftliche Abhandlungen (A), Friedrich Pfeil, Münich, p. 265-319.

Pascual, R., Ortega Hinojosa, E.J., Gondar, D., and Tonni, E. 1965. Las edades del cenozoico mamalífero de la Argentina, con especial atención en aquellas del territorio Bonaerense. Anales de la Comisión de Investigaciones de Ciencias de Buenos Aires 6: 165-193.

Patterson, B. (unpublished) Echimyidae y Octodontidae del Santacrucense.

Patterson, B., and Wood, A.E. 1982. Rodents from the Deseadan Oligocene of Bolivia and the relationships of the Caviomorpha. Bulletin of the Museum of Comparative Zoology 149: 370-543.

Pérez, M.E. 2010. A new rodent (Cavioidea, Hystricognathi) from the middle Miocene of Patagonia, mandibular homologies, and the origin of the crown group Caviodea sensu stricto. Journal of Vertebrate Paleontology 30: 1848-1859.

Pérez, M.E., and Vucetich, M.G. 2012. A revision of the fossil genus Phanomys Ameghino, 1887 (Rodentia, Hystricognathi, Cavioidea) from the early Miocene of Patagonia (Argentina) and the acquisition of euhypsodonty in Cavioidea sensu stricto. Paläntologische Zeitschrift 86: 187-204. 
Pérez, M.E., Arnal, M., Vucetich, M.G., Vieytes, E.C., and Krause, M. 2016. Los Hystricognathi del Mioceno medio de Patagonia. Implicancias sistemáticas, evolutivas, paleoambientales y paleobiogeográficas. $11^{\circ}$ Congreso de la Asociación Paleontológica Argentina (Gral. Roca), Actas: 80.

Perkins, M.E., Fleagle, J.G., Heizler, M.T., Nash, B., Bown, T.M., Tauber, A.A., and Dozo, M.T. 2012. Tephnochronology of the Miocene Santa Cruz and Pinturas formations, Argentina. In: S.F. Vizcaíno, R.F. Kay, and M.S. Bargo (Eds.), Early Miocene Paleobiology in Patagonia: High-Latitude Paleocommunities of the Santa Cruz Formation. Cambridge University Press, Cambridge, p. $23-40$.

SAS Institute. 2013. JMP Pro for Mac OS X, version 11.2.1. Cary, North Carolina.

Scott, W.B. 1905. Mammalia of the Santa Cruz beds. Part III. Glires. In: Scott, W.B. (Ed.), Reports of the Princeton University Expeditions to Patagonia 1896-1899. Princeton University Press, Princeton, p. 348-487.

Tejada-Lara, J., Salas-Gismondi, R., Pujos, F., Baby, P., Benammi, S.B., De Franceschi, D., Espurt, N., Urbina, M., and Antoine, P.-O. 2015. Life in proto-Amazonia: Middle Miocene mammals from the Fitzcarrald Arch (Peruvian Amazonia). Palaeontology 58: 341-378.

Tullberg, T. 1899. Über das System der Nagertiere: eine phylogenetische Studie. Nova Acta Regiae Societatis Scientiarium Upsaliensis 3: 1-514.

Verzi, D.H., Olivares. A.I., and Morgan, C.C. 2016. Systematics and evolutionary significance of the small Abrocomidae from the early Miocene of southern South America. Historical Biology. doi: 10.1080/08912963.2016.1168410

Villafañe, A., Pérez, M.E., Abello, A., Bedatou, E., and Bond, M. 2008. Nueva Localidad Fosilífera del Mioceno Medio en el Noroeste de la Provincia del Chubut. $3^{\circ}$ Congreso Latinoamericano de $\mathrm{Pa}$ leontología de Vertebrados (Neuquén), Actas: 265.

Vizcaíno, S.F., Kay, R.F., and Bargo, M.S. 2012. Background for a paleoecological study of the Santa Cruz Formation (late Early Miocene) on the Atlantic coast of Patagonia. In: S.F. Vizcaíno, R.F. Kay, and M.S. Bargo (Eds.), Early Miocene Paleobiology in Patagonia. Cambridge University Press, Cambridge, p. 1-22.

Vizcaíno, S.F., Bargo, M.S., and Fernicola, J.C. 2013. Expediciones paleontológicas durante los siglos XIX y XX a la Formación Santa Cruz (Mioceno Inferior, Patagonia) y destino de los fósiles. $3^{\circ}$ Congreso Argentino de Historia de la Geología (Salta), Actas: 231-246.

Vucetich, M.G. 1986. Historia de los roedores y primates en Argentina: su aporte al conocimiento de los cambios ambientales durante el Cenozoico. $4^{\circ}$ Congreso Argentino de Paleontología y Bioestratigrafía (Mendoza), Actas 2: 157-165.

Vucetich, M.G. 1991. Los roedores de Salla y Lacayani (Bolivia) y su correlación con los de otras faunas de edad Deseadense (Oligoceno). In: R. Suárez-Soruco (Ed.), Fósiles y Facies de BoliviaVol. I Vertebrados. Yacimientos Petrolíferos Fiscales Bolivianos, Santa Cruz, p. 625-629.

Vucetich, M.G., and Pérez, M.E. 2011. The putative cardiomyines (Rodentia, Cavioidea) of the middle Miocene of Patagonia (Argentina) and the differentiation of the Family Hydrochoeridae. Journal of Vertebrate Paleontology 31: 1382-1386.

Vucetich, M.G., and Ribeiro, A.M. 2003. A new and primitive rodent from the Tremembé Formation (Late Oligocene) of Brazil, with comments on the morphology of the lower premolars of Caviomorph rodents. Revista Brasileira de Paleontología 5: 73-82.

Vucetich, M.G., Mazzoni, M.M., and Pardiñas, U.F.J. 1993a. Los roedores de la Formación Collón Cura (Mioceno medio) y la Ig- nimbrita Pilcaniyeu. Ameghiniana 30: 361-381.

Vucetich, M.G., Souza Cunha, F.L., and Ferraz de Alvarenga, H.M. 1993b. Un roedor Caviomorpha de la Formación Tremembé (Cuenca de Taubaté), Estado de Sao Paulo, Brasil. Anales de la Academia Brasilera de Ciencias 65: 247-251.

Vucetich, M.G., Deschamps, C.M., Olivares, A.I., and Dozo, M.T. 2005. Capybaras, size, time and shape: a model kit. Acta Paleontologica Polonica 50: 259-272.

Vucetich, M.G., Kramarz, G.A., and Candela, M.A. 2010. Colhuehuapian rodents from Gran Barranca and other Patagonian localities: the state of the art. In: R.H. Madden, A.A. Carlini, M.G. Vucetich, and R.F. Kay (Eds.), The Paleontology of Gran Barranca Evolution and Environmental Change through the Middle Cenozoic of Patagonia. Cambridge University Press, New York, p. 202-219.

Vucetich, M.G., Dozo, M.T., Arnal, M., and Pérez, M.E. 2015a. New rodents (Mammalia) from the late Oligocene of Cabeza Blanca (Chubut) and the first rodent radiation in Patagonia. Historical Biology 27: 236-257.

Vucetich, M.G., Arnal, M., Deschamps, C.M., Pérez, M.E., and Vieytes, C.E. 2015b. A brief history of Caviomorph rodents as told by the fossil record. In: A. Vassallo, and D. Antonucci (Eds.), Biology of Caviomorh rodents: Diversity and Evolution. SAREM series A: Investigaciones Mastozoológicas, Mastozoological Research, p. 11-62.

Walton, A.H. 1990. [Rodents of the La Venta fauna, Miocene, Colombia: Biostratigraphy and paleoenvironmental implications. Ph.D. dissertation, Southern Methodist University, Dallas, USA, 159 p. Unpublished.].

Walton, A. 1997. Rodents. In: R.F. Kay, R.H. Madden, R.H. Cifelli, and J.J. Flynn (Eds.), Vertebrate Paleontology in the Neotropics: The Miocene fauna of La Venta, Colombia. Smithsonian Institution Press, Washington D.C., p. 499-519.

Waterhouse, G.E. 1839. Observations on the Rodentia, with a view to point out the groups, as indicated by the structure of the crania in this order of Mammals. Magazine of Natural History 3: 90-96.

Wible, J.R., Yuanqing, W., Chuankui, L., and Dawson, M.R. 2005. Cranial anatomy and relationships of a new tenodactyloid (Mammalia, Rodentia) from the early Eocene of Hubei Province, China. Annals of the Carnegie Museum 74: 91-150.

Wood, A.E. 1955. A revised classification of the rodents. Journal of Mammalogy 36: 165-187.

Wood, A.E., and Patterson, B. 1959. The rodents of the Deseadan Oligocene of Patagonia and the beginnings of the South American rodent radiation. Bulletin of the Museum of Comparative Zoology 120: 282-428.

Woods, C.A. and Howland, E.E. 1979. Adaptative radiation of capromyid rodents: anatomy of the masticatory apparatus. Journal of Mammalogy 60: 95-116.

Zachos, J.C., Dickens, G.R., and Zeebe, R.E. 2008. An early Cenozoic perspective on greenhouse warming and carbon-cycle dynamics. Nature 451: 279-283.

doi: 10.5710/AMGH.17.02.2017.3048

Submitted: August $19^{\text {th }}, 2016$

Accepted: February $17^{\text {th }}, 2016$ 